\title{
SESMARIAS GOIANAS NOS DOCUMENTOS DO ARQUIVO HISTÓRICO ULTRAMARINO
}

Projeto de Pesquisa de Iniciação Científica - PIC

Centro Universitário de Brasília - UniCEUB

Orientador: Deusdedith Alves Rocha Junior - Mat: 4837-4

Orientanda: Caroline de Novais de Souza - RA: 21130858

Resumo: Esta pesquisa realizou a identificação, sistematização e análise dos documentos do Arquivo Histórico Ultramarino, da cota de Goiás, referentes às solicitações e concessões de sesmarias no território colonial goiano. Ao se considerar a questão agrária no Brasil atual e as suas relações com as formas de concepção e apropriação das porções de terras por particulares durante o processo colonizador um importante tema dos estudos históricos, ensejou-se verificar de que modo foram distribuídas as propriedades privadas da terra em Goiás colonial. A sistematização dos documentos referentes à formação das sesmarias no território goiano colonial proporciona uma importante fonte para as reflexões sobre as relações de trabalho, produção e propriedade privada no campo. Assim procedeu-se a análise de uma centena de documentos, o que possibilitou verificar a distribuição espacial das sesmarias goianas durante o século XVIII e as atribuições toponímicas registradas pelos solicitantes, de onde podemos verificar a sua permanência e as representações sociais do espaço que carregam.

Palavras-chave: Sesmarias; Goiás colonial; sistema agrário.

\section{INTRODUÇÃO}

Est pesquisa tratou da formação da grande propriedade no território goiano colonial, mais especificamente da identificação das primeiras solicitações de propriedades rurais. A origem do sistema agrário no Brasil está relacionada com a propriedade da terra no período colonial e as relações políticas que se estabeleciam entre a coroa portuguesa e os colonos europeus-portugueses que migravam para o Brasil.

Assim, a interação entre o Estado português e os particulares que investiram nos processos produtivos agrícolas e pecuários apoiados pela legislação colonial foi promotora de uma burocracia e de uma gama de informações e aparatos jurídicos capazes de sustentar a empresa colonizadora, o que pode ser verificado em meio a grande massa de documentos sobre o assunto constantes nos arquivos que tratam desse período. 
A documentação do Arquivo Histórico Ultramarino, recentemente digitalizada e distribuída nas universidades brasileiras, é uma rica fonte de documentos, muitos inéditos, que se devidamente transcritos e analisados podem propiciar interpretações e revisões historiográficas, sobretudo quando se trata de questões referentes à ocupação do sertão e a questão da fronteira oeste da América Portuguesa, em especial os documentos da capitania de Goiás em meados dos setecentos, quando se detalhava o território como uma forma de apropriação política do mesmo.

A coroa portuguesa, desde fins do século XVII, passou a se organizar política e estrategicamente de um modo diferente do que fizera até então com as formas de ocupação dos interiores do território brasileiro, depois que passou a considerar a importância que a nova economia mineradora tomara para o reino. O controle da entrada de portugueses (reinóis ou brasileiros), os modos como passou a tratar a questão indígena, as novas concepções territoriais (beneficiadas pelos avanços técnicos e tecnológicos da cartografia), bem como as compreensões políticas revisadas sobre os sentidos de território e de fronteira são algumas das questões que podem configurar os percursos da pesquisa histórica em decorrência das mudanças ocorridas no processo colonizador.

Ao mesmo tempo em que organiza a ocupação dos novos territórios como a instituição política de novas capitanias, a coroa portuguesa empreende um grande esforço para conhecer, mapear e exercer outras formas de controle sobre o espaço e as sociedades indígenas que ali vivem, o que se traduz em uma infinidade de documentos descritivos, avaliativos e legislativos sobre a porção territorial que se ocupa, parcial ou integralmente. E disto resultam as movimentações de grupos indígenas e as novas formas de ocupação do território, seja pelo colonizador português ou pelo negro africano em fuga da escravidão.

Mais tarde, tomada a posse do território, primeiro por portugueses, através da revisões dos acordos com o colonizador espanhol, e depois pelo Estado brasileiro ainda em torno de conflitos com índios, quilombos e remanescentes, e antigos colonos, de um lado, e as novas formas do capital, de outro, os permanentes estudos e sentidos produzidos sobre os espaços territoriais em disputa permaneceram sendo recriados como forma de justificação da gestão do Estado sobre o território. 
É nesta perspectiva da territorialidade portuguesa em disputa com o projeto colonizador espanhol na América do Sul que se desenvolveram um lento, mas contínuo, processo de desterritorialização dos indígenas e de formação da propriedade privada da terra, principalmente por meio das práticas e normas do colonizador, ao considerar a ausência de direitos dos índios e ao mesmo tempo de aplicar a legislação portuguesa em favor dos colonos que se apropriavam das terras agora desocupadas.

A questão agrária tem uma extensa vida na historiografia brasileira, desde os seus primórdios, com a formação do Instituto Histórico e Geográfico Brasileiro e as pesquisas que trataram do processo colonizador português, não pode deixar de ser anotado a consolidação dos direitos que se impuseram sobre o território, e consequentemente sobre a distribuição de terras na forma de propriedade privada.

Assim, a formação das capitanias hereditárias, das demais doações e das sesmarias que baseavam na legislação portuguesa sobressaem na história colonizadora, ora concebida como um processo civilizador e favorável ao desenvolvimento social da futura nação, e ora de modo mais crítico, destacando as imposições e violências cometidas com os massacres e expulsões das grandes populações indígenas que estavam presentes no território, além do uso sistemático da mão-de-obra escrava africana nos processos produtivos agrícolas.

Autores como Varnhagem, com A História Geral do Brazil (1857), destacam a empreitada portuguesa como uma forma de promoção da civilização dos índios e de organização positiva do processo produtivo da terra, o que o fazia considerar a ausência de trabalho e produtividade nas sociedades indígenas. Sua concepção da colonização pressupunha que a organização da propriedade privada justificava-se por uma legislação reconhecida como válida, diante de um sistema mundial que admitia a colonização europeia um curso "natural" da história.

Capistrano de Abreu, em Capítulos de História Colonial (2002), destaca a ocupação e colonização dos territórios brasileiros por portugueses de modo crítico, considerando a complexidade que os conflitos com as sociedades indígenas passaram a viver a partir da formação das propriedades privadas sustentadas pela coroa portuguesa. Sua crítica, no entanto, não condena o processo colonizador, pois que as considerações mais questionadoras desse processo terão de esperar os autores marxistas que no século XX 
aprofundarão as questões agrária e a luta de classes, enfatizando a construção do sistema capitalista no Brasil, permeado por dependências e sujeições às metrópoles europeias e aos papéis periféricos que desempenhou.

Outras concepções sobre os processos de formação da propriedade da terra e dos processos de ocupação e produção agrária no Brasil foram formulados, tanto no campo da história, como o fez Sérgio Buarque de Holanda, como no campo da sociologia, como fizeram José de Souza Martins e Otávio lanni, ao analisarem as situações atuais da luta pela terra.

Quanto aos aspectos teóricos lançaremos mão da Análise do Discurso, buscando estudar a "língua funcionando para a produção de sentidos". Desse modo, trataremos os textos considerando que a linguagem não é transparente e que procura detectar, então, como ele significa. Vendo o texto como detentor de uma materialidade simbólica própria e significativa, com o estudo do discurso, pretende-se apreender a prática da linguagem, ou seja, o homem falando, além de procurar compreender a língua enquanto trabalho simbólico que faz e dá sentido, constitui o homem e sua história.

Por meio da linguagem, o homem transforma a realidade em que vive e a si mesmo. O homem constrói a existência humana, ou seja, confere-Ihe sentido. E é essa capacidade do homem de atribuir, incessantemente, sentidos que promove seu constante devir, e o das coisas, que interessa à Análise do Discurso. A Análise do Discurso leva em conta o homem e a língua em suas concretudes, não enquanto sistemas abstratos. Ou seja, considera os processos e as condições por meio dos quais se produz a linguagem. Assim fazendo, insere o homem e a linguagem à sua exterioridade, à sua historicidade.

\section{MATERIAIS E MÉTODOS}

Metodologicamente realizamos uma análise dos vários processos históricos que caracterizam a busca pela ocupação do território e a política de fronteiras do Brasil, no Planalto Central, especialmente no rio Tocantins. Implica em pesquisa que reúne, examina e classifica informações produzidas por relatos de viajantes. Estas são fontes relevantes para

se entender os sentidos de territorialidade e fronteira nos diversos momentos, na região. É 
ainda uma crítica e uma interpretação das fontes para se retirar informações e se ter um melhor entendimento e esclarecimento do tema. E por fim, é uma interpretação, articulando as informações obtidas na crítica das fontes, tanto as cartas quanto os mapas analisados, sobre o contexto histórico.

\section{RESULTADOS}

Walter Costa Porto observa que as feitorias e capitanias hereditárias resultaram de atos políticos do rei de Portugal, que conferia poderes aos donatários, mas não exatamente "direitos sobre o solo" (PORTO, sd, p.21).

Nessa mesma perspectiva de considerar a posse da terra uma exclusividade do rei, e a concessão ao colono um direito político do uso da terra, Raymundo Faoro concluía que "os forais - a carta foral - era um pacto entre o rei e o povo, [que] asseguravam o predomínio do soberano, o predomínio já em caminho para o absolutismo, ao estipularem que a terra não teria outro senhor senão o rei" (FAORO, 1996, p.7).

Em sentido contrário, considerando o sistema de capitanias hereditárias um "ensaio de feudalismo" que "não vingou" (PRADO Jr, Epub), Caio Prado Jr insiste que "o caráter mais profundo da colonização reside na forma pela qual se distribuiu a terra" (PRADO Jr, Epub), considerando que daí surgiu definitivamente a propriedade privada de tipo capitalista.

Os forais dos donatários determinavam que as terras fossem distribuídas em sesmarias aos moradores. Ficava portanto a apropriação da terra vazada em determinada forma jurídica, pois a designação sesmaria não se referia genericamente a qualquer forma de doação, mas, pelo contrário, subordinava especificamente a certos caracteres jurídicos. A propriedade do sesmeiro era alodial, isto é, plena, não consagrando outro ônus que não o pagamento da dízima da Ordem de Cristo, que afinal não passa de um simples imposto, e outras restrições, como os monopólios reais, servidões públicas de água, caminhos etc. (PRADO Jr. Epub).

Assim, não é possível conferir a essa estrutura um "caráter feudal", pois "as terras eram alienáveis por livre disposição dos proprietários e não criavam laço algum de dependência pessoal" (PRADO Jr., Epub). Essa discussão, que não se esgota nos termos aqui apresentados, nem se resolve de modo definitivo, pois o caráter privado da propriedade da terra não impedia a compreensão de que o rei exercia o senhorio sobre o reino de modo soberano, serve como ponto de partida para a problematização do caráter da propriedade da terra no processo colonizador.

Se de um lado a propriedade da terra confere ao colono um direito fundamentado nas leis portuguesas, desprezando as outras formas de relação com a terra, desenhadas pelas sociedades indígenas, também se estabelece uma ambivalência, por outro lado, com o sentido de soberania que vigia na sociedade de Antigo Regime. O rei é o senhor absoluto dos territórios conquistados, como se pode observar nos títulos que se atribuem.

- É possível aprofundar a pesquisa considerando os títulos que se atribuem aos reis portugueses: D. Philippe, per graça de Deos, Rey de Portugal e dos Algarves, d'aquém e d'além mar, em Africa Senhor de Guiné, e da Conquista, 
Navegação e Commercio de Etiopia, Arabia, Persia e da India. A todos nossos subditos e vasallos destes nossos Reinos e Senhorios de Portugal, saúde, etc.

- As questões sobre as sesmarias:

- Como elas estão propostas nas Ordenações e nas outras leis.

- Como elas foram adaptadas na colonização do Brasil.

- Como elas foram implementadas no território goiano.

- As hipóteses:

- O processo colonizador do Brasil Central, particularmente o território goiano, foi rapidamente desenvolvido por um processo de parcelamento da terra, formando fazendas (de pecuária e agricultura) que logo buscaram o reconhecimento do Estado português através de pedidos de registros de sesmarias (verificar outras formas).

- A distribuição territorial das fazendas cujos proprietários solicitaram a concessão de sesmarias coincide com as grandes regiões mineradoras do território goiano.

- É possível considerar que a colonização portuguesa do Brasil Central desenvolveu-se por um processo de formação de uma ampla rede formada por vilas, estradas e fazendas.

- Política de ocupação territorial = empreendida pela coroa portuguesa através dos processos (burocráticos) de concessão de sesmarias (dentre outras formas datas de mineração etc.).

- A concessão de sesmarias na América portuguesa exigiu adaptações das ordenações (Afonsinas - 1446 a 1500/1514; Manuelinas - 1514 a 1603; Filipinas - 1603 até a independência do Brasil). Criaram-se leis esparsas que atendiam às necessidades que surgiam durante o processo de colonização (ver Osório, 1990, p.27).

- As Ordenações Afonsinas e Manuelinas definem sesmarias:

Propriamente as datas de terras, casais (casas de campo ou granjearias) ou pardieiros (casas velhas ameaçando ruína, já arruinadas ou desabitadas) que foram ou são de alguns senhorios que já em outro tempo foram lavradas e aproveitadas e agora não o são (SILVA, 2015, p.12 apud FARIA, 2001, p.259).

- As Ordenações Filipinas acrescentam que as doações "poderiam ser feitas em matos maninhos, ou matas e bravios, que nunca foram lavradas e aproveitadas" (SILVA, 2015, p12 apud FARIA, 2001, p.259).

- Este acréscimo permite que se contemple na política de terras portuguesa a principal característica da sua colônia na América, a ausência de propriedade privada (e por oposição, a ausência de propriedade abandonada), e assim se estabeleça uma "ordem jurídico-política da colonização lusitana, estabelecendo critérios de repartição de terras, condições de posse e prazo para o uso (SILVA, 2015, p.12 apud FARIA, 2001, p.15).

- Relativiza-se nesse momento o estatuto da capitania hereditária, ainda que ele permaneça.

- O controle do processo de concessão e ocupação de terras na América portuguesa, mobilizou governantes interessados em consolidar a ocupação territorial por parte de Portugal, e colonos, os sesmeiros que procuravam garantir seus direitos (SILVA, 2015, p.12). assim, esses sesmeiros buscavam o reconhecimento legal dos seus direitos, enquanto os governantes ditavam 
normas que ordenavam e controlavam os processos de concessão de terras. Esses procedimentos alimentaram uma intensa burocracia que gerava cargos, leis (alvarás, bandos, provisões), solicitações e títulos (cartas).

- A descoberta do ouro em Goiás e a organização da burocracia = a formação da comarca de Goiás e sua evolução para capitania, ampliando o corpo administrativo.

- A dispersão dos achados auríferos em Goiás e as grandes regiões mineradoras = o rápido surgimento das povoações e estradas, entremeadas por fazendas.

- A presença, na burocracia da comarca de Goiás, de responsáveis pelo encaminhamento das solicitações de sesmarias e os primeiros pedidos.

- "Assim como em Minas Gerais as primeiras cartas de sesmarias concedidas, consagraram as posses aos que assim justificaram junto ao governo" (CARRARA, 2001, p.87).

- Conclusões: 1) foi rápido o processo de ocupação de terras em Goiás demandando o reconhecimento do Estado português das propriedades particulares; 2) a toponímia goiana foi rapidamente estabelecida, como se pode observar pelas solicitações dos sesmeiros; 3) a importância do domínio legal (para os colonos e os governantes).

Definição das quatro grandes regiões da capitania de Goiás: Tomando o rio Tocantins como um divisor natural que em uma linha vertical divide o lado Leste e o lado Oeste da capitania de Goiás, traça-se uma linha horizontal na altura das nascentes deste mesmo rio (sendo tais nascentes os rios das Almas e Maranhão), onde se estabelece um lado Norte e um lado Sul. Assim, todo o percurso do rio Tocantins fica ao norte e divide a capitania em Leste e Oeste. Ao sul, até a margem norte do rio Grande, que faz divisa com as capitanias de São Paulo e Minas Gerais, divide-se também um lado Leste e Oeste, seguindo uma linha imaginária que continuaria o rio Tocantins (ou seguindo o rio Meia Ponte, que segue para o rio Grande). Temos assim uma cruz que teria em cada um dos seus lados as seguintes vilas e arraiais como centro: ao Sudoeste, Vila Boa de Goiás, Anta e Jaraguá; ao Sudeste, Meyaponte, Santa Luzia e Bonfim; ao Nordeste, São José do Tocantins, Traíras, São Félix, Cavalcante, Arrayas, Barra do Palma e Natividade; e ao Noroeste, Pillar, Crixás e Guarinos.

Documentos: 137; Noroeste: 15; Sudoeste: 25; Nordeste: 42; Sudeste: 19; Região não identificada: 27; Não referente a sesmaria: 9

Vila de São João das Duas Barras; Porto Real; Monte do Carmo; Pontal; Amaro Leite; Pillar; Crixás; São Chapada; Almas; Duro; Natividade; Miguel das Tesouras; Goarinos; Santa Príncipe; Conceição do Tocantins; Rita. Barra da Palma (Paranã); Arraia; Morro do Chapéu (Monte Alegre de Goiás); Chapada de São Félix; São Félix; São Domingos; Cavalcante; Forte; São José do Tocantins (Niquelândia); Trayras; Água Quente; Cocal; Santa Rita; Muquém; Flores de Goiás; Mato Grosso; Santa Rosa; Lavrinhas; Maranhão.

Vila Boa de Goiás; Anta; Barra; Ferreiro; Couros; Montes Claros; Corumbá; Jaraguá; Ouro Fino; Curralinho; Anicuns; Meyaponte; Santa Luzia; Bomfim; 


\begin{tabular}{|l|l|}
\hline Pilões. & $\begin{array}{l}\text { Santa Cruz; Catalão; Uberabinha } \\
\text { (Uberlândia) ; Uberaba; Araxá; } \\
\text { Desemboque. }\end{array}$ \\
\hline
\end{tabular}

Ref: mapa Capitania de Goyaz (1809) - Divisão em Julgados. In Luiz Antônio Silva e Souza (1812/1967). O descobrimento da Capitania de Goyaz. Goiânia, Ed. UFG, 2003.

NÚCLEOS URBANOS:

\section{REGIÃO 1 - NOROESTE}

- Pilões

- Crixás

- Monjolo (Paragem)

- Pilar

- São Patrício

- Morrinhos

NÚCLEOS RURAIS:

- Sítio Frei Reinaldo

- Sítio abaixo do Poço Grande

- Lages

CURSOS D'ÁGUA:

- Rio Tombadouro

- Rio Preto

- Rio Traíras

- Rio Vermelho

- Ribeirão da Missa

- Ribeirão Taquaruçu

- Ribeirão da Paciência

- Ribeirão dos Macacos

- Rio das Almas

- Rio Buriti

OUTROS ACIDENTES GEOGRÁFICOS:

NÚCLEOS URBANOS:

\section{REGIÃO 2 - SUDOESTE}

- Vila Boa

- Antas

- Paragem do Rio Bugres

- Curral das Éguas (Lugar)

- Chapada (Paragem)

- Jaguará (Paragem)

- Ribeirão dos Bois (Paragem)

NÚCLEOS RURAIS:

- Sítio São Pedro

- (Entre o capitão Gerônimo Martins da Cunha e Alexandre Afonso Veloso)

- Sítio de Tibaldo Paes 
- Fazendinha

CURSOS D'ÁGUA:

- Rio Capivari

- Ribeirão das Antas

- Rio Bugres

- Rio Urú

- Rio do Peixe

- Rio do Ferreiro (Ferreira)

- Ribeirão de Bernardo Gonçalves

- Ribeirão das Pedras

- Ribeirão Fartura

- Ribeirão das Contendas

- Rio das Almas

- Ribeirão dos Bois

OUTROS ACIDENTES GEOGRÁFICOS:

- Matos baldios do distrito de Vila Boa

- Matos e campos da Paciência

- (Caminho que vai...)

- Morro do Caxambu

- Serra Dourada

NÚCLEOS URBANOS:

\section{REGIÃO 3 - SUDESTE}

- Meia Ponte

- (Paragem das margens do Rio Maranhão)

- Furnas (Paragem)

- Cocal

- Santa Luzia

NÚCLEOS RURAIS:

- Sítio Tavares

- Barreiro (Lugar)

CURSOS D'ÁGUA:

- Rio das Pedras

- Ribeirão Grande

- Rio Maranhão

- Córrego Palmital

- Rio do Peixe

- Ribeirão Água Limpa

- Rio São Bartolomeu

- Rio dos Patos

- Córrego Jaraguá

- Riacho das Pedras

- Rio das Almas

- Ribeirão Santa Luzia 
OUTROS ACIDENTES GEOGRÁFICOS:

- (Barra do Ribeirão do caminho que vai de Meia Ponte ao arraial do Pilar)

- Serra Caiçara

- (Entre a roça que foi de João Alves de Braga até o Riacho das Pedras)

- Sertão do Paraíba

- (No sertão de fora do Rio São Bartolomeu)

NÚCLEOS URBANOS:

\section{REGIÃO 4 - NORDESTE}

- Natividade

- Bom Sucesso (Paragem)

- Barra da Palma

- Paragem junto ao Rio Traíras

- Minas de São Félix

- São Félix

- Mocambo de Santa Ana

- São José do Tocantins

- Paranã

- Cavalcante

- Cocal

- Carmo

- Pedras (Paragem)

- Bocaina (Paragem)

- Olhos D’Água

- Traíras

NÚCLEOS RURAIS:

- Fazenda São Lourenço

- Fazenda do Saco

- Sítio da Bagagem

- Engenho de São Domingos

- Sítio Canabrava

- Fazenda Espírito Santo

- (Entre as sesmarias de José Rodrigues Lobato e Manoel Ferreira de Castro)

- Sítio Acaba Vida

CURSOS D'ÁGUA:

- Ribeirão Taquaruçu

- Rio do Peixe

- Rio Pernatinga (Paranã)

- Rio da Palma

- Ribeirão do Taquaral

- Ribeirão das Pedras

- Ribeirão Crixás

- Rio Traíras

- Córrego Fundo

- Rio Maranhão

- Rio Manuel Alves 
- Rio Claro

- Rio São Félix

- Rio Prata

- Rio Tocantins

- Rio Canabrava

- Ribeirão Beliago

- Ribeirão das Areias

- Riacho Fundo

- Ribeirão das Pedras

- Ribeirão São Patrício

- Córrego que faz barra no Rio Manuel Alves

- Ribeirão Mutuca

- Rio das Mortes

- Ribeirão Acaba Vida

- Rio Bagagem

- Córrego "Entrapualha"(?)

OUTROS ACIDENTES GEOGRÁFICOS:

- Terras Novas

- Detrás da Serra de Traíras

- Serra do Baul

- Serra de São José

- Ao pé de uma serra...

- Sertão do Corriola

NÚCLEOS URBANOS:

\section{REGIÃO NÃO IDENTIFICADA}

- Lugar chamado Calhamares

- Lugar chamado Parí

- Campo Alegre

- São Patrício

- Riachão

- Retiro

- Bonito

- Ribeirão Sousa (Paragem)

- Campo Grande

- Boa Vista (Paragem)

- Tapera (Paragem)

- Buriti (Paragem)

NÚCLEOS RURAIS:

- Sítio do Mato Grosso

CURSOS D'ÁGUA:

- Rio de São Patrício

- Ribeirão Beliago

- Rio Bagagem

- Rio Urú 
- Ribeirão do Bugres

- Ribeirão Vermelho de Cubas

- Ribeirão Vermelho

- Rio Preto

- Ribeirão Sousa

- Córrego do Monjolo

- Riacho Grande

OUTROS ACIDENTES GEOGRÁFICOS:

- Pé do Morro Grande

- Serra de São Bento

- Matos do Barbalho

- Borda do Mato Grosso

Categorias toponímicas:

- Antroponímia: nomes de pessoas.

- Arqueotoponímia: objetos ou fatos.

- Astrotoponímia: corpos celestes.

- Biotoponímia (zootoponímia; fitotoponímia): animais e vegetais.

- Cardinotoponímia: posições geográficas.

- Cromotoponímia: cores.

- Cronotoponímia: tempo.

- Dimensiotoponímia: dimensões.

- Ecotoponímia: habitações.

- Etnotoponímia: pátrio e étnico.

- Geotoponímia: relevo e forma do terreno.

- Hagiotoponímia: devoção religiosa.

- Meteorotoponímia: clima.

- Morfotoponímia: forma.

\begin{tabular}{|c|c|c|c|c|c|c|c|c|}
\hline \multicolumn{9}{|c|}{ SESMARIAS DE GOIÁS COLONIAL } \\
\hline $\begin{array}{l}\mathrm{N}^{\circ} \\
\text { Doc. }\end{array}$ & $\begin{array}{l}\text { Local/Dat } \\
\text { a }\end{array}$ & Tipo Doc. & Solicitante & Solicitado & Solicitação & Localidade & $\begin{array}{l}\text { Localizaçõ } \\
\text { es }\end{array}$ & Comentários \\
\hline 0007 & $\begin{array}{l}\text { Goiás, } 10 \\
\text { de } \\
\text { outubro } \\
\text { de } 1733\end{array}$ & $\begin{array}{l}\text { Requerimen } \\
\text { to }\end{array}$ & $\begin{array}{l}\text { Francisco } \\
\text { Ferreira da } \\
\text { Silva }\end{array}$ & $\begin{array}{l}\{\text { rei }\} \text { D. } \\
\text { Joao V }\end{array}$ & $\begin{array}{l}\text { Provimento } \\
\text { por tempo } \\
\text { de um ano } \\
\text { no oficio de } \\
\text { tabelião e } \\
\text { escrivão. }\end{array}$ & $\begin{array}{l}\text { Datas e } \\
\text { Sesmarias do } \\
\text { Distrito das } \\
\text { Minas de Goiás. }\end{array}$ & & \\
\hline 0016 & $\begin{array}{l}\text { Goiás, } \\
20 \text { de } \\
\text { março } \\
\text { de1735 }\end{array}$ & Carta & $\begin{array}{l}\text { Gregório } \\
\text { Dias da Silva }\end{array}$ & $\begin{array}{l}\{\text { rei }\} \text { D. } \\
\text { Joao V }\end{array}$ & $\begin{array}{l}\text { Avaliação } \\
\text { do } \\
\text { rendimento } \\
\text { do oficio de } \\
\text { escrivão. }\end{array}$ & $\begin{array}{l}\text { Escrivão da } \\
\text { Superintendênci } \\
\text { a-Geral e das } \\
\text { Datas e } \\
\text { Sesmarias das } \\
\text { Minas de Goiás. }\end{array}$ & & $\begin{array}{l}\text { Anexo: } 3 \text { docs. } \\
\text { AUH- Goiás } \\
\text { AHU_ACL_CU_0 } \\
08, \text { Cx. } 1, \text { D.16 }\end{array}$ \\
\hline 0018 & $\begin{array}{l}?-11 \mathrm{de} \\
\text { novembr } \\
\text { o de } 1735\end{array}$ & $\begin{array}{l}\text { Requerimen } \\
\text { to }\end{array}$ & $\begin{array}{l}\text { Francisco da } \\
\text { Silva } \\
\text { Henriques }\end{array}$ & $\begin{array}{l}\{\text { rei }\} \text { D. } \\
\text { Joao V }\end{array}$ & $\begin{array}{l}\text { Provimento } \\
\text { para } \\
\text { exercer os } \\
\text { ofícios de } \\
\text { Escrivão, } \\
\text { Execução e } \\
\text { Tabelião. }\end{array}$ & $\begin{array}{l}\text { Do publico, } \\
\text { Judicial e Notas } \\
\text { e Nas Datas de } \\
\text { Sesmaria e na } \\
\text { Comarca de } \\
\text { Goiás. }\end{array}$ & & AHU_ACL_CU_ \\
\hline 0019 & $\begin{array}{l}\text { Goiás, } 17 \\
\text { de } \\
\text { dezembro } \\
1735\end{array}$ & $\begin{array}{l}\text { Requerimen } \\
\text { to }\end{array}$ & $\begin{array}{l}\text { Francisco da } \\
\text { Silva } \\
\text { Henriques }\end{array}$ & $\begin{array}{l}\{\text { rei }\} \text { D. } \\
\text { Joao V }\end{array}$ & $\begin{array}{l}\text { Provimento } \\
\text { do Oficio } \\
\text { de Escrivão } \\
\text { pelo tempo }\end{array}$ & $\begin{array}{l}\text { Superintendênci } \\
\text { a-Geral das } \\
\text { Minas de Goiás. }\end{array}$ & & \\
\hline
\end{tabular}




\begin{tabular}{|c|c|c|c|c|c|c|c|c|}
\hline & & & & & deum ano. & & & \\
\hline 0020 & $\begin{array}{l}\text { Goiás. } \\
23 \text { de } \\
\text { dezembro } \\
\text { de } 1735\end{array}$ & $\begin{array}{l}\text { Requerimen } \\
\text { to }\end{array}$ & $\begin{array}{l}\text { Francisco } \\
\text { Ferreira da } \\
\text { Silva }\end{array}$ & $\begin{array}{l}\text { \{rei }\} \text { D. } \\
\text { Joao V }\end{array}$ & $\begin{array}{l}\text { Outra } \\
\text { provisão } \\
\text { para } \\
\text { confirmar o } \\
\text { seu Oficio } \\
\text { de Tabelião } \\
\text { e Escrivão. }\end{array}$ & $\begin{array}{l}\text { Do publico, } \\
\text { Judicial e Notas } \\
\text { e das Datas de } \\
\text { Sesmaria das } \\
\text { Minas de Goiás. }\end{array}$ & & \\
\hline 0061 & $\begin{array}{l}\text { Goiás, } 21 \\
\text { de julho } \\
\text { de } 1739\end{array}$ & $\begin{array}{l}\text { Requerimen } \\
\text { to }\end{array}$ & $\begin{array}{l}\text { Francisco } \\
\text { Ferreira da } \\
\text { Silva }\end{array}$ & $\begin{array}{l}\{\text { rei }\} \text { D. } \\
\text { Joao V }\end{array}$ & $\begin{array}{l}\text { Novo } \\
\text { provimento } \\
\text { para } \\
\text { continuar } \\
\text { exercendo } \\
\text { os ofícios } \\
\text { de tabelião } \\
\text { e escrivão. }\end{array}$ & $\begin{array}{l}\text { Do Publico, } \\
\text { Judicial e Notas } \\
\text { e das Datas e } \\
\text { Sesmarias de } \\
\text { Vila Boa. }\end{array}$ & & \\
\hline 0123 & $\begin{array}{l}\text { Lisboa, } \\
29 \text { de } \\
\text { Janeiro } \\
\text { de } 1741\end{array}$ & Aviso & $\begin{array}{l}\text { Joao dos } \\
\text { Santos Leite } \\
\text { Bressane } \\
\text { (Secretário da } \\
\text { Junta dos } \\
\text { Três Estados) }\end{array}$ & $\begin{array}{l}\text { Manuel } \\
\text { Caetano } \\
\text { Lopes de } \\
\text { Lavre( } \\
\text { Secretário } \\
\text { do } \\
\text { Conselho } \\
\text { Ultramarin } \\
\text { o) }\end{array}$ & $\begin{array}{l}\text { Ordenar as } \\
\text { informaçõe } \\
\text { s } \\
\text { necessárias } \\
\text { sobre o } \\
\text { requeriment } \\
\text { o escrito } \\
\text { pelo } \\
\text { tabelião e } \\
\text { escrivão, } \\
\text { sobre a } \\
\text { avaliação } \\
\text { de seu } \\
\text { oficio. }\end{array}$ & Lisboa & & \\
\hline 0353 & $\begin{array}{l}\text { Goiás, } 05 \\
\text { de Abril } \\
\text { de } 1748\end{array}$ & $\begin{array}{l}\text { Requerimen } \\
\text { to }\end{array}$ & $\begin{array}{l}\text { Manuel da } \\
\text { Costa Pereira }\end{array}$ & $\begin{array}{l}\text { \{rei }\} \text { D. } \\
\text { Joao V }\end{array}$ & $\begin{array}{l}\text { Confirmaçã } \\
\text { o da Carta } \\
\text { de } \\
\text { Sesmaria }\end{array}$ & $\begin{array}{l}\text { Nas minas de } \\
\text { Goiás, na região } \\
\text { do arraial de } \\
\text { Meipote. }\end{array}$ & & \\
\hline 0491 & $\begin{array}{l}\text { ?, } 27 \text { de } \\
\text { Setembro } \\
\text { de } 1751\end{array}$ & $\begin{array}{l}\text { Requerimen } \\
\text { to }\end{array}$ & $\begin{array}{l}\text { Antônio da } \\
\text { Serra Ribeiro }\end{array}$ & $\begin{array}{l}\{\text { rei }\} \text { D. } \\
\text { José }\end{array}$ & $\begin{array}{l}\text { Confirmaçã } \\
\text { o da Carta } \\
\text { de } \\
\text { Sesmaria }\end{array}$ & $\begin{array}{l}\text { Nos matos de } \\
\text { baldios dos } \\
\text { Distritos de } \\
\text { Vila Boa, } \\
\text { capitania de } \\
\text { Goiás. }\end{array}$ & & \\
\hline 0554 & $\begin{array}{l}\text { Lisboa, } \\
18 \text { de } \\
\text { Abril de } \\
1753\end{array}$ & Consulta & $\begin{array}{l}\text { Francisco } \\
\text { Tossi } \\
\text { Colombina }\end{array}$ & $\begin{array}{l}\text { Conselho } \\
\text { Ultramarin } \\
\text { o do rei D. } \\
\text { José }\end{array}$ & $\begin{array}{l}\text { As mercês } \\
\text { de sesmaria } \\
\text { e } \\
\text { privilégios } \\
\text { que lhe } \\
\text { foram } \\
\text { concedidos } \\
\text { para abrir o } \\
\text { caminho } \\
\text { novo. }\end{array}$ & $\begin{array}{l}\text { São Paulo e } \\
\text { Vila de Santos } \\
\text { até as vilas de } \\
\text { Goiás e Cuiabá. }\end{array}$ & & $\begin{array}{l}\text { Anexo:3 docs. } \\
\text { Obs.: doc incomp. } \\
\text { AHU-Goiás }\end{array}$ \\
\hline 0633 & $\begin{array}{l}\text { Goiás, } 09 \\
\text { de Março } \\
\text { de } 1754\end{array}$ & $\begin{array}{l}\text { Requerimen } \\
\text { to }\end{array}$ & $\begin{array}{l}\text { Bento Pereira } \\
\text { Gomes }\end{array}$ & $\begin{array}{l}\{\text { rei }\} \text { D. } \\
\text { José }\end{array}$ & $\begin{array}{l}\text { Confirmaçã } \\
\text { o da carta } \\
\text { de } \\
\text { Sesmaria }\end{array}$ & $\begin{array}{l}\text { No lugar } \\
\text { chamado das } \\
\text { Antas, no rio } \\
\text { Capivari }\end{array}$ & $\begin{array}{l}\text { e Ribeirão } \\
\text { das Antas, } \\
\text { capitania } \\
\text { de Goiás }\end{array}$ & \\
\hline 0634 & $\begin{array}{l}\text { Goiás, } 09 \\
\text { de Março } \\
\text { de } 1754\end{array}$ & $\begin{array}{l}\text { Requerimen } \\
\text { to }\end{array}$ & $\begin{array}{l}\text { Mateus } \\
\text { Lopes da } \\
\text { Silva }\end{array}$ & $\begin{array}{l}\{\text { rei }\} \text { D. } \\
\text { José }\end{array}$ & $\begin{array}{l}\text { Confirmaçã } \\
\text { o da carta } \\
\text { de } \\
\text { Sesmaria }\end{array}$ & $\begin{array}{l}\text { No distrito de } \\
\text { Natividade, na } \\
\text { paragem } \\
\text { chamada Bom } \\
\text { sucesso }\end{array}$ & $\begin{array}{l}\text { E Ribeirão } \\
\text { do } \\
\text { Taquarussú } \\
\text {, que faz } \\
\text { barra no rio } \\
\text { do Peixe, } \\
\text { capitania } \\
\text { de Goiás. }\end{array}$ & \\
\hline 0635 & $\begin{array}{l}\text { Goiás, } 29 \\
\text { de Abril } \\
\text { de } 1754\end{array}$ & $\begin{array}{l}\text { Requerimen } \\
\text { to }\end{array}$ & $\begin{array}{l}\text { Manuel } \\
\text { Rodrigues } \\
\text { Nunes }\end{array}$ & $\begin{array}{l}\text { \{rei\} D. } \\
\text { José }\end{array}$ & $\begin{array}{l}\text { Confirmaçã } \\
\text { o da carta } \\
\text { de } \\
\text { Sesmaria }\end{array}$ & $\begin{array}{l}\text { Na paragem do } \\
\text { rio Bugres }\end{array}$ & $\begin{array}{l}\text { Termo de } \\
\text { Vila Boa, } \\
\text { capitania } \\
\text { de Goiás }\end{array}$ & $\begin{array}{l}\text { Anexo:4 docs. } \\
\text { AHU-Goiás }\end{array}$ \\
\hline 0639 & $\begin{array}{l}\text { Goiás, } 01 \\
\text { de Junho } \\
\text { de } 1754\end{array}$ & $\begin{array}{l}\text { Requerimen } \\
\text { to }\end{array}$ & $\begin{array}{l}\text { José de } \\
\text { Moreira }\end{array}$ & $\begin{array}{l}\{\text { rei }\} \text { D. } \\
\text { José }\end{array}$ & $\begin{array}{l}\text { Confirmaçã } \\
\text { o da carta } \\
\text { de } \\
\text { Sesmaria }\end{array}$ & $\begin{array}{l}\text { Nas cabeceiras } \\
\text { do rio Bugres, } \\
\text { em Vila Boa, } \\
\text { capitania de } \\
\text { Goiás. }\end{array}$ & & \\
\hline 0672 & $\begin{array}{l}\text { Vila Boa, } \\
21 \text { de } \\
\text { Novembr }\end{array}$ & Carta & $\begin{array}{l}\text { D. Marcos de } \\
\text { Noronha ( } \\
\text { governador e }\end{array}$ & $\begin{array}{l}\text { \{rei\} D. } \\
\text { José }\end{array}$ & $\begin{array}{l}\text { Em } \\
\text { resposta á } \\
\text { provisão }\end{array}$ & Vila boa & & \\
\hline
\end{tabular}




\begin{tabular}{|c|c|c|c|c|c|c|c|c|}
\hline & o de 1754 & & $\begin{array}{l}\text { capitão- } \\
\text { general } \\
\text { nomeado } \\
\text { para Goiás ) }\end{array}$ & & $\begin{array}{l}\text { sobre as } \\
\text { cartas de } \\
\text { Datas de } \\
\text { Sesmaria } \\
\text { que se } \\
\text { mandaram } \\
\text { passar em } \\
\text { governo de } \\
\text { Goiás. }\end{array}$ & & & \\
\hline 0689 & $\begin{array}{l}\text { Goiás, } 12 \\
\text { de } \\
\text { Dezembr } \\
\text { o de } 1754\end{array}$ & $\begin{array}{l}\text { Requerimen } \\
\text { to }\end{array}$ & $\begin{array}{l}\text { Manuel da } \\
\text { Costa Matos }\end{array}$ & $\begin{array}{l}\text { \{rei }\} \text { D. } \\
\text { José }\end{array}$ & $\begin{array}{l}\text { Confirmaçã } \\
\text { o da carta } \\
\text { de } \\
\text { Sesmaria }\end{array}$ & $\begin{array}{l}\text { Na paragem da } \\
\text { vertente do rio } \\
\text { dos Bugres, } \\
\text { capitania de } \\
\text { Goiás. }\end{array}$ & $\begin{array}{l}\text { Termo de } \\
\text { Vila Boa, }\end{array}$ & \\
\hline 0761 & $\begin{array}{l}\text { Goiás, } 15 \\
\text { de } \\
\text { Setembro } \\
\text { de } 1755\end{array}$ & $\begin{array}{l}\text { Requerimen } \\
\text { to }\end{array}$ & $\begin{array}{l}\text { Gregório } \\
\text { Vieira da } \\
\text { Silva ( } \\
\text { morador em } \\
\text { São Félix de } \\
\text { Carlos } \\
\text { Marinho) }\end{array}$ & $\begin{array}{l}\{\text { rei }\} \text { D. } \\
\text { José }\end{array}$ & $\begin{array}{l}\text { Confirmaçã } \\
\text { o de carta } \\
\text { de } \\
\text { Sesmaria }\end{array}$ & $\begin{array}{l}\text { No sítio } \\
\text { chamado Frei } \\
\text { Reinaldo, nas } \\
\text { cabeceiras do } \\
\text { Tombadouro até } \\
\text { o Paiol }\end{array}$ & $\begin{array}{l}\text { E } \\
\text { finalizando } \\
\text { no fundo } \\
\text { do rio Preto } \\
\text { até os } \\
\text { Pilões, } \\
\text { capitania } \\
\text { do Goiás. }\end{array}$ & $\begin{array}{l}\text { Anexo: } 3 \text { doc. } \\
\text { AHU-Goiás }\end{array}$ \\
\hline 0768 & $\begin{array}{l}\text { Goiás, } 11 \\
\text { de } \\
\text { Outubro } \\
\text { de } 1755\end{array}$ & $\begin{array}{l}\text { Requerimen } \\
\text { to }\end{array}$ & $\begin{array}{l}\text { Antônio } \\
\text { Botelho } \\
\text { Pimentel }\end{array}$ & $\begin{array}{l}\{\text { rei }\} \text { D. } \\
\text { José }\end{array}$ & $\begin{array}{l}\text { Confirmaçã } \\
\text { o de carta } \\
\text { de } \\
\text { Sesmaria }\end{array}$ & $\begin{array}{l}\text { No distrito da } \\
\text { Barra da Palma, } \\
\text { no terreno } \\
\text { chamado Santa } \\
\text { Cruz, }\end{array}$ & $\begin{array}{l}\text { Sai na } \\
\text { barra do } \\
\text { Pernatinga } \\
\text { das Terras } \\
\text { Novas, } \\
\text { capitania } \\
\text { de Goiás }\end{array}$ & $\begin{array}{l}\text { Anexo: } 2 \text { doc. } \\
\text { AHU-Goiás }\end{array}$ \\
\hline 0809 & $\begin{array}{l}\text { Goiás, } 09 \\
\text { de } \\
\text { Dezembr } \\
\text { o de } 1756\end{array}$ & $\begin{array}{l}\text { Requerimen } \\
\text { to }\end{array}$ & $\begin{array}{l}\text { Dionísio } \\
\text { Gomes Leal } \\
\text { (morador das } \\
\text { Minas de } \\
\text { Tocantins, } \\
\text { comarca de } \\
\text { Goiás) } \\
\end{array}$ & $\begin{array}{l}\text { \{rei }\} \text { D. } \\
\text { José }\end{array}$ & $\begin{array}{l}\text { Confirmaçã } \\
\text { o da carta } \\
\text { de } \\
\text { Sesmaria }\end{array}$ & $\begin{array}{l}\text { Na paragem } \\
\text { chamada o } \\
\text { Ribeirão do } \\
\text { Taquaral, } \\
\text { capitania de } \\
\text { Goiás. }\end{array}$ & & \\
\hline 0810 & $\begin{array}{l}\text { Goiás, } 09 \\
\text { de } \\
\text { Dezembr } \\
\text { o de } 1756\end{array}$ & $\begin{array}{l}\text { Requerimen } \\
\text { to }\end{array}$ & $\begin{array}{l}\text { Álvaro } \\
\text { Gomes Leal } \\
\text { (morador das } \\
\text { Minas de } \\
\text { Tocantins, } \\
\text { comarca de } \\
\text { Goiás) }\end{array}$ & $\begin{array}{l}\text { \{rei }\} \text { D. } \\
\text { José }\end{array}$ & $\begin{array}{l}\text { Confirmaçã } \\
\text { o da carta } \\
\text { de } \\
\text { Sesmaria }\end{array}$ & $\begin{array}{l}\text { Na paragem } \\
\text { chamada o } \\
\text { Ribeirão das } \\
\text { Pedras, } \\
\text { capitania de } \\
\text { Goiás. }\end{array}$ & & \\
\hline 0811 & $\begin{array}{l}\text { Goiás, } 14 \\
\text { de } \\
\text { Dezembr } \\
\text { o de } 1756\end{array}$ & $\begin{array}{l}\text { Requerimen } \\
\text { to }\end{array}$ & $\begin{array}{l}\text { Duarte } \\
\text { Ferreira } \\
\text { Bahia( } \\
\text { morador no } \\
\text { distrito de } \\
\text { Traíras, } \\
\text { comarca de } \\
\text { Goiás) } \\
\end{array}$ & $\begin{array}{l}\text { \{rei }\} \text { D. } \\
\text { José }\end{array}$ & $\begin{array}{l}\text { Confirmaçã } \\
\text { o da carta } \\
\text { de } \\
\text { Sesmaria }\end{array}$ & $\begin{array}{l}\text { De um sítio que } \\
\text { possui detrás da } \\
\text { serra de Traíras, } \\
\text { capitania de } \\
\text { Goiás. }\end{array}$ & & \\
\hline 0830 & $\begin{array}{l}\text { Goiás, } 07 \\
\text { de } \\
\text { Fevereiro } \\
\text { de } 1757\end{array}$ & $\begin{array}{l}\text { Requerimen } \\
\text { to }\end{array}$ & $\begin{array}{l}\text { Caetano de } \\
\text { Almeida }\end{array}$ & $\begin{array}{l}\text { \{rei }\} \text { D. } \\
\text { José }\end{array}$ & $\begin{array}{l}\text { Confirmaçã } \\
\text { o da carta } \\
\text { de } \\
\text { Sesmaria }\end{array}$ & $\begin{array}{l}\text { Na paragem } \\
\text { junto ao rio } \\
\text { Traíras, no } \\
\text { ribeirão Crixás, } \\
\text { capitania de } \\
\text { Goiás. }\end{array}$ & & \\
\hline 0831 & $\begin{array}{l}\text { Goiás, } 12 \\
\text { de } \\
\text { Fevereiro } \\
\text { de } 1757\end{array}$ & $\begin{array}{l}\text { Requerimen } \\
\text { to }\end{array}$ & $\begin{array}{l}\text { Antônio } \\
\text { Rodrigues } \\
\text { Frota( } \\
\text { sargento- } \\
\text { mor) }\end{array}$ & $\begin{array}{l}\{\text { rei }\} \text { D. } \\
\text { José }\end{array}$ & $\begin{array}{l}\text { Confirmaçã } \\
\text { o da carta } \\
\text { de } \\
\text { Sesmaria }\end{array}$ & $\begin{array}{l}\text { No lugar } \\
\text { chamado Pé do } \\
\text { Morro Grande, } \\
\text { capitania de } \\
\text { Goiás. }\end{array}$ & & \\
\hline 0862 & $\begin{array}{l}\text { Goiás, } 17 \\
\text { de } \\
\text { Setembro } \\
\text { de } 1757\end{array}$ & $\begin{array}{l}\text { Requerimen } \\
\text { to }\end{array}$ & $\begin{array}{l}\text { Diogo da } \\
\text { Costa Portela }\end{array}$ & $\begin{array}{l}\{\text { rei }\} \text { D. } \\
\text { José }\end{array}$ & $\begin{array}{l}\text { Confirmaçã } \\
\text { o da carta } \\
\text { de } \\
\text { Sesmaria }\end{array}$ & $\begin{array}{l}\text { Nas Minas de } \\
\text { São Félix, na } \\
\text { fazenda } \\
\text { chamada São } \\
\text { Lourenço, } \\
\text { capitania de } \\
\text { Goiás. }\end{array}$ & & \\
\hline 0863 & $\begin{array}{l}\text { Goiás, } 24 \\
\text { de } \\
\text { Setembro } \\
\text { de } 1757\end{array}$ & $\begin{array}{l}\text { Requerimen } \\
\text { to }\end{array}$ & $\begin{array}{l}\text { Duarte } \\
\text { Pereira } \\
\text { Gomes( } \\
\text { coronel) }\end{array}$ & $\begin{array}{l}\text { \{rei }\} \text { D. } \\
\text { José }\end{array}$ & $\begin{array}{l}\text { Confirmaçã } \\
\text { o da carta } \\
\text { de } \\
\text { Sesmaria }\end{array}$ & $\begin{array}{l}\text { Junto ao rio de } \\
\text { Traíras, } \\
\text { capitania de } \\
\text { Goiás. }\end{array}$ & & \\
\hline 0868 & Goiás, 19 & Requerimen & Domingos & $\{$ rei $\}$ D. & Confirmaçã & No lugar & & \\
\hline
\end{tabular}




\begin{tabular}{|c|c|c|c|c|c|c|c|c|}
\hline & $\begin{array}{l}\text { de } \\
\text { Outubro } \\
\text { de } 1757\end{array}$ & to & $\begin{array}{l}\text { Rodrigues e } \\
\text { Paulo de } \\
\text { Oliveira }\end{array}$ & José & $\begin{array}{l}\text { o da carta } \\
\text { de } \\
\text { Sesmaria }\end{array}$ & $\begin{array}{l}\text { chamado } \\
\text { Fazenda do } \\
\text { Saco, distrito de } \\
\text { Natividade, } \\
\text { capitania de } \\
\text { Goiás. }\end{array}$ & & \\
\hline 0869 & $\begin{array}{l}\text { Goiás, } 19 \\
\text { de } \\
\text { Outubro } \\
\text { de } 1757\end{array}$ & $\begin{array}{l}\text { Requerimen } \\
\text { to }\end{array}$ & $\begin{array}{l}\text { Domingos } \\
\text { Rodrigues e } \\
\text { Paulo de } \\
\text { Oliveira }\end{array}$ & $\begin{array}{l}\{\text { rei }\} \text { D. } \\
\text { José }\end{array}$ & $\begin{array}{l}\text { Confirmaçã } \\
\text { o da carta } \\
\text { de } \\
\text { Sesmaria }\end{array}$ & $\begin{array}{l}\text { No lugar } \\
\text { chamado } \\
\text { Fazenda do } \\
\text { Saco, distrito de } \\
\text { Natividade, } \\
\text { capitania de } \\
\text { Goiás. }\end{array}$ & & \\
\hline 0874 & $\begin{array}{l}\text { Goiás, } 14 \\
\text { de } \\
\text { Dezembr } \\
\text { o de } 1757\end{array}$ & $\begin{array}{l}\text { Requerimen } \\
\text { to }\end{array}$ & $\begin{array}{l}\text { José Pereira } \\
\text { da Silva }\end{array}$ & $\begin{array}{l}\{\text { rei }\} \text { D. } \\
\text { José }\end{array}$ & $\begin{array}{l}\text { Confirmaçã } \\
\text { o da carta } \\
\text { de } \\
\text { Sesmaria }\end{array}$ & $\begin{array}{l}\text { No lugar } \\
\text { chamado } \\
\text { Mocambo de } \\
\text { Santa Ana, } \\
\text { distrito de São } \\
\text { Félix, capitania } \\
\text { de Goiás. }\end{array}$ & & \\
\hline 0903 & $\begin{array}{l}\text { Goiás, } 17 \\
\text { de } \\
\text { Agosto } \\
\text { de } 1758\end{array}$ & $\begin{array}{l}\text { Requerimen } \\
\text { to }\end{array}$ & $\begin{array}{l}\text { Agostinho } \\
\text { Pinheiro } \\
\text { Caldas( } \\
\text { guarda-mor) }\end{array}$ & $\begin{array}{l}\{\text { rei }\} \text { D. } \\
\text { José }\end{array}$ & $\begin{array}{l}\text { Confirmaçã } \\
\text { o da carta } \\
\text { de } \\
\text { Sesmaria }\end{array}$ & $\begin{array}{l}\text { No distrito de } \\
\text { São José do } \\
\text { Tocantins }\end{array}$ & $\begin{array}{l}\text { Junto ao } \\
\text { córrego } \\
\text { Fundo que } \\
\text { faz barra } \\
\text { no rio } \\
\text { Maranhão, } \\
\text { capitania } \\
\text { de Goiás. }\end{array}$ & \\
\hline 0945 & $\begin{array}{l}\text { Goiás } 10 \\
\text { de } \\
\text { Novembr } \\
\text { o de } 1759\end{array}$ & $\begin{array}{l}\text { Requerimen } \\
\text { to }\end{array}$ & $\begin{array}{l}\text { Barnabé } \\
\text { Moreira de } \\
\text { Paiva }\end{array}$ & $\begin{array}{l}\text { rei [D. } \\
\text { José] }\end{array}$ & $\begin{array}{l}\text { Confirmaçã } \\
\text { o da carta } \\
\text { de } \\
\text { Sesmaria }\end{array}$ & $\begin{array}{ll}\text { freguesia } & \text { de } \\
\text { São José } & \text { do } \\
\text { Tocantins, } & \\
\text { capitania } & \text { de } \\
\text { Goiás. } & \end{array}$ & & \\
\hline 0946 & $\begin{array}{l}\text { Goiás, } 23 \\
\text { de } \\
\text { Novembr } \\
\text { o de } 1759\end{array}$ & $\begin{array}{l}\text { Requerimen } \\
\text { to }\end{array}$ & $\begin{array}{l}\text { António } \\
\text { Rodrigues } \\
\text { Frota }\end{array}$ & $\begin{array}{l}\text { rei [D. } \\
\text { José] }\end{array}$ & $\begin{array}{l}\text { Confirmaçã } \\
\text { o da carta } \\
\text { de } \\
\text { Sesmaria }\end{array}$ & $\begin{array}{l}\text { No sítio } \\
\text { chamado } \\
\text { Tavares, distrito } \\
\text { de Meiaponte, } \\
\text { capitania de } \\
\text { Goiás. }\end{array}$ & & \\
\hline 0949 & $\begin{array}{l}\text { Goiás, } 18 \\
\text { de } \\
\text { Janeiro } \\
\text { de } 1760\end{array}$ & $\begin{array}{l}\text { Requerimen } \\
\text { to }\end{array}$ & $\begin{array}{l}\text { Alexandre } \\
\text { Pinto Lobo }\end{array}$ & $\begin{array}{l}\text { rei [D. } \\
\text { José] }\end{array}$ & $\begin{array}{l}\text { Confirmaçã } \\
\text { o da carta } \\
\text { de } \\
\text { Sesmaria }\end{array}$ & $\begin{array}{l}\text { No rio das } \\
\text { Pedras, distrito } \\
\text { de Meiaponte, } \\
\text { capitania de } \\
\text { Goiás. }\end{array}$ & & \\
\hline 0960 & $\begin{array}{l}\text { Goiás } 26 \\
\text { de Abril } \\
\text { de } 1760\end{array}$ & $\begin{array}{l}\text { Requerimen } \\
\text { to }\end{array}$ & $\begin{array}{l}\text { Domingos } \\
\text { Martins Pinto }\end{array}$ & $\begin{array}{l}\text { rei [D. } \\
\text { José] }\end{array}$ & $\begin{array}{l}\text { Confirmaçã } \\
\text { o da carta } \\
\text { de } \\
\text { Sesmaria }\end{array}$ & $\begin{array}{l}\text { No lugar } \\
\text { chamado Curral } \\
\text { das Éguas, } \\
\text { distrito de Vila } \\
\text { boa, capitania } \\
\text { de Goiás. }\end{array}$ & & \\
\hline 1000 & $\begin{array}{l}\text { Goiás, } 25 \\
\text { de Junho } \\
\text { de } 1760\end{array}$ & $\begin{array}{l}\text { Requerimen } \\
\text { to }\end{array}$ & $\begin{array}{l}\text { Domingos } \\
\text { Rodrigues e } \\
\text { Paulo de } \\
\text { Oliveira }\end{array}$ & $\begin{array}{l}\text { rei [D. } \\
\text { José] }\end{array}$ & $\begin{array}{l}\text { Confirmaçã } \\
\text { o da carta } \\
\text { de } \\
\text { Sesmaria }\end{array}$ & $\begin{array}{l}\text { No distrito de } \\
\text { Natividade, } \\
\text { entre os rios de } \\
\text { Manuel Alves e } \\
\text { o do Peixe, } \\
\text { capitania de } \\
\text { Goiás. }\end{array}$ & & \\
\hline 1004 & $\begin{array}{l}\text { Goiás, } 06 \\
\text { de } \\
\text { Agosto } \\
\text { de } 1760\end{array}$ & $\begin{array}{l}\text { Requerimen } \\
\text { to }\end{array}$ & $\begin{array}{l}\text { Eugenio } \\
\text { Gonsalves } \\
\text { dos Santos e } \\
\text { Manuel } \\
\text { Ferreira } \\
\text { Martins } \\
\end{array}$ & $\begin{array}{l}\text { rei [D. } \\
\text { José] }\end{array}$ & $\begin{array}{l}\text { Confirmaçã } \\
\text { o da carta } \\
\text { de } \\
\text { Sesmaria }\end{array}$ & $\begin{array}{l}\text { Nas minas de } \\
\text { São Félix, junto } \\
\text { a cabeceira do } \\
\text { rio Claro, } \\
\text { capitania de } \\
\text { Goiás. }\end{array}$ & & \\
\hline 1005 & $\begin{array}{l}\text { Goiás, } 06 \\
\text { de } \\
\text { Agosto } \\
\text { de } 1760\end{array}$ & $\begin{array}{l}\text { Requerimen } \\
\text { to }\end{array}$ & $\begin{array}{l}\text { Eugenio } \\
\text { Gonsalves } \\
\text { dos Santos }\end{array}$ & $\begin{array}{l}\text { rei [D. } \\
\text { José] }\end{array}$ & $\begin{array}{l}\text { Confirmaçã } \\
\text { o da carta } \\
\text { de } \\
\text { Sesmaria }\end{array}$ & $\begin{array}{l}\text { Nas minas de } \\
\text { São Félix, }\end{array}$ & $\begin{array}{l}\text { Partindo } \\
\text { pela parte } \\
\text { Norte com } \\
\text { a serra do } \\
\text { Baul e } \\
\text { vertentes } \\
\text { para o rio } \\
\text { de São }\end{array}$ & \\
\hline
\end{tabular}




\begin{tabular}{|c|c|c|c|c|c|c|c|c|}
\hline & & & & & & & $\begin{array}{l}\text { Félix, } \\
\text { capitania } \\
\text { de Goiás. }\end{array}$ & \\
\hline 1007 & $\begin{array}{l}\text { Goiás, } 06 \\
\text { de } \\
\text { Agosto } \\
\text { de } 1760\end{array}$ & $\begin{array}{l}\text { Requerimen } \\
\text { to }\end{array}$ & $\begin{array}{l}\text { Antônio } \\
\text { Barbosa de } \\
\text { Brito }\end{array}$ & $\begin{array}{l}\text { rei [D. } \\
\text { José] }\end{array}$ & $\begin{array}{l}\text { Confirmaçã } \\
\text { o da carta } \\
\text { de } \\
\text { Sesmaria }\end{array}$ & $\begin{array}{l}\text { No sítio da } \\
\text { Bagagem, } \\
\text { cabeceira do } \\
\text { ribeirão de São } \\
\text { Félix, capitania } \\
\text { de Goiás }\end{array}$ & & \\
\hline 1046 & $\begin{array}{l}\text { Goiás, } 13 \\
\text { de julho } \\
\text { de } 1761\end{array}$ & $\begin{array}{l}\text { Requerimen } \\
\text { to }\end{array}$ & $\begin{array}{l}\text { João Antônio } \\
\text { Peixoto }\end{array}$ & $\begin{array}{l}\text { rei [D. } \\
\text { José] }\end{array}$ & $\begin{array}{l}\text { Confirmaçã } \\
\text { o da carta } \\
\text { de } \\
\text { Sesmaria }\end{array}$ & $\begin{array}{l}\text { No lugar } \\
\text { chamado } \\
\text { Calhamares, } \\
\text { capitania de } \\
\text { Goiás. }\end{array}$ & & \\
\hline 1047 & $\begin{array}{l}\text { Goiás, } 24 \\
\text { de Julho } \\
\text { de } 1761\end{array}$ & $\begin{array}{l}\text { Requerimen } \\
\text { to }\end{array}$ & $\begin{array}{l}\text { Luís João } \\
\text { Ferreira } \\
\text { (capitão) }\end{array}$ & $\begin{array}{l}\text { rei [D. } \\
\text { José] }\end{array}$ & $\begin{array}{l}\text { Confirmaçã } \\
\text { o da carta } \\
\text { de } \\
\text { Sesmaria }\end{array}$ & $\begin{array}{l}\text { No sitio } \\
\text { chamado São } \\
\text { Pedro, na } \\
\text { Paciência, } \\
\text { capitania de } \\
\text { goiás. }\end{array}$ & & \\
\hline 1051 & $\begin{array}{l}\text { Goiás, } 17 \\
\text { de } \\
\text { Setembro } \\
\text { de } 1761\end{array}$ & $\begin{array}{l}\text { Requerimen } \\
\text { to }\end{array}$ & $\begin{array}{l}\text { Domingos } \\
\text { Martins Pinto }\end{array}$ & $\begin{array}{l}\text { rei [D. } \\
\text { José] }\end{array}$ & $\begin{array}{l}\text { Confirmaçã } \\
\text { o da carta } \\
\text { de } \\
\text { Sesmaria }\end{array}$ & $\begin{array}{l}\text { No rio Urú, } \\
\text { perto de Vila } \\
\text { Boa, capitania } \\
\text { de Goiás. }\end{array}$ & & $\begin{array}{l}\text { Que houve compra } \\
\text { a João Alves } \\
\text { Vieira. }\end{array}$ \\
\hline 1052 & $\begin{array}{l}\text { Goiás, } 17 \\
\text { de } \\
\text { setembro } \\
\text { de } 1761\end{array}$ & $\begin{array}{l}\text { Requerimen } \\
\text { to }\end{array}$ & $\begin{array}{l}\text { Francisco da } \\
\text { Costa } \\
\text { Guimarães }\end{array}$ & $\begin{array}{l}\text { rei [D. } \\
\text { José] }\end{array}$ & $\begin{array}{l}\text { Confirmaçã } \\
\text { o da carta } \\
\text { de } \\
\text { Sesmaria }\end{array}$ & $\begin{array}{l}\text { No arraial do } \\
\text { Pilar, junto a } \\
\text { um ribeirão } \\
\text { chamado Buriti, } \\
\text { capitania de } \\
\text { Goiás. }\end{array}$ & & \\
\hline 1055 & $\begin{array}{l}\text { Goiás, } 16 \\
\text { Outubro } \\
\text { de } 1761\end{array}$ & $\begin{array}{l}\text { Requerimen } \\
\text { to }\end{array}$ & $\begin{array}{l}\text { Manuel } \\
\text { Martins }\end{array}$ & $\begin{array}{l}\text { rei [D. } \\
\text { José] }\end{array}$ & $\begin{array}{l}\text { Confirmaçã } \\
\text { o da carta } \\
\text { de } \\
\text { Sesmaria }\end{array}$ & $\begin{array}{l}\text { No rio Prata, } \\
\text { entre a estradas } \\
\text { ou caminhos do } \\
\text { Paranã e } \\
\text { Cavalcante, } \\
\text { capitania de } \\
\text { Goiás. }\end{array}$ & & \\
\hline 1056 & $\begin{array}{l}\text { Goiás, } 16 \\
\text { de } \\
\text { Outubro } \\
\text { de } 1761\end{array}$ & $\begin{array}{l}\text { Requerimen } \\
\text { to }\end{array}$ & $\begin{array}{l}\text { Caetano } \\
\text { Pereira } \\
\text { Cortes( } \\
\text { morador das } \\
\text { minas de São } \\
\text { Félix ) }\end{array}$ & $\begin{array}{l}\text { rei [D. } \\
\text { José] }\end{array}$ & $\begin{array}{l}\text { Confirmaçã } \\
\text { o da carta } \\
\text { de } \\
\text { Sesmaria }\end{array}$ & $\begin{array}{l}\text { Na outra parte } \\
\text { do rio } \\
\text { Tocantins, por } \\
\text { nome } \\
\text { Maranhão. }\end{array}$ & $\begin{array}{l}\text { Dividindo } \\
\text { com os rios } \\
\text { da } \\
\text { Canabrava } \\
\text { e São } \\
\text { Félix, } \\
\text { capitania } \\
\text { de Goiás. }\end{array}$ & \\
\hline 1069 & $\begin{array}{l}\text { Goiás, } 04 \\
\text { de } \\
\text { Dezembr } \\
\text { o de } 1761\end{array}$ & $\begin{array}{l}\text { Requerimen } \\
\text { to }\end{array}$ & $\begin{array}{l}\text { Manuel } \\
\text { Teodoro de } \\
\text { Sequeira }\end{array}$ & $\begin{array}{l}\text { rei [D. } \\
\text { José] }\end{array}$ & $\begin{array}{l}\text { Confirmaçã } \\
\text { o da carta } \\
\text { de } \\
\text { Sesmaria }\end{array}$ & $\begin{array}{l}\text { No lugar da } \\
\text { barra do } \\
\text { ribeirão do } \\
\text { caminho que } \\
\text { vai de } \\
\text { Meiaponte ao } \\
\text { arraial do Pilar, } \\
\text { capitania de } \\
\text { Goiás. }\end{array}$ & & \\
\hline 1070 & $\begin{array}{l}\text { Goiás, } 15 \\
\text { de } \\
\text { Dezembr } \\
\text { o de } 1761\end{array}$ & $\begin{array}{l}\text { Requerimen } \\
\text { to }\end{array}$ & $\begin{array}{l}\text { Manuel } \\
\text { Teodoro de } \\
\text { Sequeira }\end{array}$ & $\begin{array}{l}\text { rei [D. } \\
\text { José] }\end{array}$ & $\begin{array}{l}\text { Confirmaçã } \\
\text { o da carta } \\
\text { de } \\
\text { Sesmaria }\end{array}$ & $\begin{array}{l}\text { Junto ao } \\
\text { ribeirão Grande } \\
\text { que tem as } \\
\text { cabeceiras } \\
\text { acima da } \\
\text { passagem. }\end{array}$ & $\begin{array}{l}\text { Que está no } \\
\text { caminho } \\
\text { que vai de } \\
\text { Meiaponte } \\
\text { ao arraial } \\
\text { do Pilar, } \\
\text { capitania } \\
\text { de Goiás. }\end{array}$ & \\
\hline 1074 & $\begin{array}{l}\text { Goiás, } 08 \\
\text { de } \\
\text { Fevereiro } \\
\text { de } 1762\end{array}$ & $\begin{array}{l}\text { Requerimen } \\
\text { to }\end{array}$ & $\begin{array}{l}\text { José Pereira } \\
\text { da Silva }\end{array}$ & $\begin{array}{l}\text { rei [D. } \\
\text { José] }\end{array}$ & $\begin{array}{l}\text { Confirmaçã } \\
\text { o da carta } \\
\text { de } \\
\text { Sesmaria }\end{array}$ & $\begin{array}{l}\text { No Mocambo } \\
\text { de Santa Ana, } \\
\text { distrito de das } \\
\text { minas de São } \\
\text { Félix, capitania } \\
\text { de Goiás. }\end{array}$ & & \\
\hline 1114 & $\begin{array}{l}\text { Vila Boa, } \\
16 \text { de } \\
\text { Outubro } \\
\text { de } 1762\end{array}$ & $\begin{array}{l}\text { Carta de } \\
\text { Sesmaria }\end{array}$ & $\begin{array}{l}\text { Joao Manual } \\
\text { de Melo ( } \\
\text { governador e } \\
\text { capitão- } \\
\text { general de } \\
\text { Goiás) } \\
\end{array}$ & $\begin{array}{l}\text { Francisco } \\
\text { de Campos } \\
\text { Silva }\end{array}$ & $\begin{array}{l}\text { Concedend } \\
\text { o-lhe meia } \\
\text { légua de } \\
\text { terra em } \\
\text { quadra }\end{array}$ & $\begin{array}{l}\text { Na paragem do } \\
\text { rio de São } \\
\text { Patrício, no } \\
\text { lugar onde } \\
\text { chamam Parí, } \\
\text { capitania de }\end{array}$ & & \\
\hline
\end{tabular}




\begin{tabular}{|c|c|c|c|c|c|c|c|c|}
\hline & & & & & & Goiás. & & \\
\hline 1168 & $\begin{array}{l}\text { Goiás, } 06 \\
\text { de } \\
\text { Agosto } \\
\text { de } 1763\end{array}$ & $\begin{array}{l}\text { Requerimen } \\
\text { to }\end{array}$ & $\begin{array}{l}\text { Antônio } \\
\text { Francisco } \\
\text { Dias }\end{array}$ & $\begin{array}{l}\text { rei [D. } \\
\text { José] }\end{array}$ & $\begin{array}{l}\text { Confirmaçã } \\
\text { o da carta } \\
\text { de } \\
\text { Sesmaria }\end{array}$ & $\begin{array}{l}\text { Na paragem } \\
\text { chamada } \\
\text { Monjolo, no } \\
\text { distrito de Pilar, } \\
\text { capitania de } \\
\text { Goiás. }\end{array}$ & & \\
\hline 1170 & $\begin{array}{l}\text { Goiás, } 27 \\
\text { de } \\
\text { Agosto } \\
\text { de } 1763\end{array}$ & $\begin{array}{l}\text { Requerimen } \\
\text { to }\end{array}$ & $\begin{array}{l}\text { Matias da } \\
\text { Silva Freitas } \\
\text { ( doutor) }\end{array}$ & $\begin{array}{l}\text { rei [D. } \\
\text { José] }\end{array}$ & $\begin{array}{l}\text { Confirmaçã } \\
\text { o da carta } \\
\text { de } \\
\text { Sesmaria }\end{array}$ & $\begin{array}{l}\text { No distrito do } \\
\text { Pilar, capitania } \\
\text { de goiás. }\end{array}$ & & \\
\hline $\begin{array}{l}\# 118 \\
3\end{array}$ & $\begin{array}{l}\text { Goiás, } 22 \\
\text { de } \\
\text { Novembr } \\
\text { o de } \\
1763\end{array}$ & $\begin{array}{l}\text { Requerimen } \\
\text { to }\end{array}$ & $\begin{array}{l}\text { \#Rita } \\
\text { Rodrigues } \\
\text { Neves ( viúva } \\
\text { de Manuel da } \\
\text { Costa } \\
\text { Portela) }\end{array}$ & $\begin{array}{l}\text { rei [D. } \\
\text { José] }\end{array}$ & $\begin{array}{l}\text { Confirmaçã } \\
\text { o da carta } \\
\text { de } \\
\text { Sesmaria }\end{array}$ & $\begin{array}{l}\text { Entre o capitão } \\
\text { Jeronimo } \\
\text { Martins da } \\
\text { Cunha e } \\
\text { Alexandre } \\
\text { Afonso Veloso, } \\
\text { em frente ao } \\
\text { morro do } \\
\text { Caxambú. }\end{array}$ & $\begin{array}{l}\text { No } \\
\text { caminho } \\
\text { que vai de } \\
\text { Vila Boa } \\
\text { ao arraial } \\
\text { do Pilar, } \\
\text { capitania } \\
\text { do Goiás. }\end{array}$ & \\
\hline 1184 & $\begin{array}{l}\text { Goiás, } 24 \\
\text { de } \\
\text { Novembr } \\
\text { o de } 1763\end{array}$ & $\begin{array}{l}\text { Requerimen } \\
\text { to }\end{array}$ & $\begin{array}{l}\text { Alexandre } \\
\text { Afonsso } \\
\text { Veloso }\end{array}$ & $\begin{array}{l}\text { rei [D. } \\
\text { José] }\end{array}$ & $\begin{array}{l}\text { Confirmaçã } \\
\text { o da carta } \\
\text { de } \\
\text { Sesmaria }\end{array}$ & $\begin{array}{l}\text { Na paragem que } \\
\text { fica entre as } \\
\text { cabeceias do rio } \\
\text { do Peixe e as } \\
\text { do ferreiro }\end{array}$ & $\begin{array}{l}\text { No } \\
\text { caminho } \\
\text { que vai de } \\
\text { Vila Boa } \\
\text { para o } \\
\text { arraial do } \\
\text { Pilar, } \\
\text { capitania } \\
\text { de Goiás. }\end{array}$ & \\
\hline 1239 & $\begin{array}{l}\text { Goiás, } 28 \\
\text { de } \\
\text { Outubro } \\
\text { de } 1763\end{array}$ & $\begin{array}{l}\text { Requerimen } \\
\text { to }\end{array}$ & $\begin{array}{l}\text { Barnabé } \\
\text { Moreira de } \\
\text { Piva } \\
\text { (sargento- } \\
\text { mor no } \\
\text { distrito do } \\
\text { Tocantins) }\end{array}$ & $\begin{array}{l}\text { rei [D. } \\
\text { José] }\end{array}$ & $\begin{array}{l}\text { Confirmaçã } \\
\text { o da carta } \\
\text { de } \\
\text { Sesmaria }\end{array}$ & $\begin{array}{l}\text { Detrás da serra } \\
\text { de São José, na } \\
\text { margem do } \\
\text { ribeirão Traíras. }\end{array}$ & $\begin{array}{l}\text { Onde faz } \\
\text { barra o } \\
\text { ribeirão } \\
\text { Beliago, } \\
\text { capitania } \\
\text { de Goiás. }\end{array}$ & \\
\hline 1240 & $\begin{array}{l}\text { Goiás, } \\
28 / \text { de } \\
\text { Outubro } \\
\text { de } 1763\end{array}$ & $\begin{array}{l}\text { Requerimen } \\
\text { to }\end{array}$ & $\begin{array}{l}\text { Manuel } \\
\text { Alves } \\
\text { Cardoso } \\
\text { (sargento- } \\
\text { mor) } \\
\end{array}$ & $\begin{array}{l}\text { rei [D. } \\
\text { José] }\end{array}$ & $\begin{array}{l}\text { Confirmaçã } \\
\text { o da carta } \\
\text { de } \\
\text { Sesmaria }\end{array}$ & $\begin{array}{l}\text { No ribeirão } \\
\text { Beliago, detrás } \\
\text { da serra, } \\
\text { capitania de } \\
\text { goiás. }\end{array}$ & & \\
\hline 1241 & $\begin{array}{l}\text { Goiás, } \\
31 / \text { de } \\
\text { Outubro } \\
\text { de } 1763\end{array}$ & $\begin{array}{l}\text { Requerimen } \\
\text { to }\end{array}$ & $\begin{array}{l}\text { Manuel } \\
\text { Ferreira } \\
\text { Torres }\end{array}$ & $\begin{array}{l}\text { rei [D. } \\
\text { José] }\end{array}$ & $\begin{array}{l}\text { Confirmaçã } \\
\text { o da carta } \\
\text { de } \\
\text { Sesmaria }\end{array}$ & $\begin{array}{l}\text { Na cabeceira do } \\
\text { rio Bagagem, da } \\
\text { outra parte da } \\
\text { serra de São } \\
\text { Bento, capitania } \\
\text { de Goiás. }\end{array}$ & & \\
\hline 1243 & $\begin{array}{l}\text { Goiás, } 07 \\
\text { de } \\
\text { Novembr } \\
\text { o de } 1763\end{array}$ & $\begin{array}{l}\text { Requerimen } \\
\text { to }\end{array}$ & $\begin{array}{l}\text { Manuel } \\
\text { Ferreira da } \\
\text { Silva }\end{array}$ & $\begin{array}{l}\text { rei [D. } \\
\text { José] }\end{array}$ & $\begin{array}{l}\text { Confirmaçã } \\
\text { o da carta } \\
\text { de } \\
\text { Sesmaria }\end{array}$ & $\begin{array}{l}\text { Na cabeceira do } \\
\text { rio Bagagem, na } \\
\text { outra parte da } \\
\text { serra de São } \\
\text { Bento, capitania } \\
\text { de Goiás. }\end{array}$ & & \\
\hline 1244 & $\begin{array}{l}\text { Goiás, } 05 \\
\text { de } \\
\text { Dezembr } \\
\text { o de } 1763\end{array}$ & $\begin{array}{l}\text { Requerimen } \\
\text { to }\end{array}$ & $\begin{array}{l}\text { José } \\
\text { Gonsalves } \\
\text { Dias }\end{array}$ & $\begin{array}{l}\text { rei [D. } \\
\text { José] }\end{array}$ & $\begin{array}{l}\text { Confirmaçã } \\
\text { o da carta } \\
\text { de } \\
\text { Sesmaria }\end{array}$ & $\begin{array}{l}\text { No engenho de } \\
\text { São Domingos. }\end{array}$ & $\begin{array}{l}\text { Entre o } \\
\text { arraial de } \\
\text { São Félix e } \\
\text { o de } \\
\text { Cavalcante, } \\
\text { capitania } \\
\text { de Goiás. }\end{array}$ & \\
\hline 1319 & $\begin{array}{l}\text { Goiás, } 05 \\
\text { de } \\
\text { outubro } \\
\text { de } 1765\end{array}$ & $\begin{array}{l}\text { Requerimen } \\
\text { to }\end{array}$ & $\begin{array}{l}\text { Domingos } \\
\text { Vaz } \\
\text { Mascarenhas( } \\
\text { morador no } \\
\text { arraial do } \\
\text { Pilar) } \\
\end{array}$ & $\begin{array}{l}\text { rei [D. } \\
\text { José] }\end{array}$ & $\begin{array}{l}\text { Confirmaçã } \\
\text { o da carta } \\
\text { de } \\
\text { Sesmaria }\end{array}$ & $\begin{array}{l}\text { No distrito do } \\
\text { mesmo arraial, } \\
\text { capitania de } \\
\text { Goiás. }\end{array}$ & & \\
\hline 1326 & $\begin{array}{l}\text { Goiás, } 06 \\
\text { de } \\
\text { Dezembr } \\
\text { o de } 1765\end{array}$ & $\begin{array}{l}\text { Requerimen } \\
\text { to }\end{array}$ & $\begin{array}{l}\text { Joaquim de } \\
\text { Macedo } \\
\text { Pereira Costa } \\
\text { Rangel } \\
\text { (morador do } \\
\text { arraial do } \\
\text { Cocal, } \\
\text { distrito de }\end{array}$ & $\begin{array}{l}\text { rei [D. } \\
\text { José] }\end{array}$ & $\begin{array}{l}\text { Confirmaçã } \\
\text { o da carta } \\
\text { de } \\
\text { Sesmaria }\end{array}$ & $\begin{array}{l}\text { Nas margens do } \\
\text { rio Maranhão, } \\
\text { ao pé de uma } \\
\text { serra, capitania } \\
\text { de Goiás. }\end{array}$ & & \\
\hline
\end{tabular}




\begin{tabular}{|c|c|c|c|c|c|c|c|}
\hline & & & Traíras & & & & \\
\hline $\begin{array}{l}134 \\
1\end{array}$ & $\begin{array}{l}\text { Goiás, } 03 \\
\text { de Abril } \\
\text { de } 1766\end{array}$ & $\begin{array}{l}\text { Requerimen } \\
\text { to }\end{array}$ & $\begin{array}{l}\text { \# Bernarda } \\
\text { Ferraz de } \\
\text { Araújo e } \\
\text { Veronica dias } \\
\text { Leite }\end{array}$ & $\begin{array}{l}\text { rei [D. } \\
\text { José] }\end{array}$ & $\begin{array}{l}\text { Confirmaçã } \\
\text { o da carta } \\
\text { de } \\
\text { Sesmaria }\end{array}$ & $\begin{array}{l}\text { Na cabeceira do } \\
\text { rio Bugres, } \\
\text { distrito de Vila } \\
\text { Boa, capitania } \\
\text { de Goiás. }\end{array}$ & \\
\hline 1345 & $\begin{array}{l}\text { Goiás, } 09 \\
\text { de Abril } \\
\text { de } 1766\end{array}$ & $\begin{array}{l}\text { Requerimen } \\
\text { to }\end{array}$ & $\begin{array}{l}\text { Francisco } \\
\text { pereira } \\
\text { Velho( } \\
\text { morador da } \\
\text { freguesia de } \\
\text { Vila Boa }\end{array}$ & $\begin{array}{l}\text { rei [D. } \\
\text { José] }\end{array}$ & $\begin{array}{l}\text { Confirmaçã } \\
\text { o da carta } \\
\text { de } \\
\text { Sesmaria }\end{array}$ & $\begin{array}{l}\text { No lugar por } \\
\text { detrás da Serra } \\
\text { Dourada, no } \\
\text { ribeirão } \\
\text { chamado de } \\
\text { Bernardo } \\
\text { Gonsalves, } \\
\text { capitania de } \\
\text { Goiás. }\end{array}$ & \\
\hline 1348 & $\begin{array}{l}\text { Goiás, } 18 \\
\text { de abril } \\
\text { de } 1766\end{array}$ & $\begin{array}{l}\text { Requerimen } \\
\text { to }\end{array}$ & $\begin{array}{l}\text { Margarida da } \\
\text { Silva Buena( } \\
\text { viúva de João } \\
\text { Bicudo de } \\
\text { Brito e } \\
\text { moradora nos } \\
\text { matos de } \\
\text { Barbalho, } \\
\text { acima do rio } \\
\text { Urú. }\end{array}$ & $\begin{array}{l}\text { rei [D. } \\
\text { José] }\end{array}$ & $\begin{array}{l}\text { Confirmaçã } \\
\text { o da carta } \\
\text { de } \\
\text { Sesmaria }\end{array}$ & $\begin{array}{l}\text { Na referida } \\
\text { paragem, } \\
\text { capitania de } \\
\text { goiás. }\end{array}$ & \\
\hline 1350 & $\begin{array}{l}\text { Goiás, } 05 \\
\text { de Maio } \\
\text { de } 1766\end{array}$ & $\begin{array}{l}\text { Requerimen } \\
\text { to }\end{array}$ & $\begin{array}{l}\text { Manuel } \\
\text { Nunes } \\
\text { Fernandes } \\
\text { (morador no } \\
\text { arraial do } \\
\text { Ouro Fino) } \\
\end{array}$ & $\begin{array}{l}\text { rei [D. } \\
\text { José] }\end{array}$ & $\begin{array}{l}\text { Confirmaçã } \\
\text { o da carta } \\
\text { de } \\
\text { Sesmaria }\end{array}$ & $\begin{array}{l}\text { No ribeirão das } \\
\text { Pedras, } \\
\text { capitania de } \\
\text { Goiás. }\end{array}$ & \\
\hline 1351 & $\begin{array}{l}\text { Goiás, } 14 \\
\text { de Junho } \\
\text { de } 1766\end{array}$ & $\begin{array}{l}\text { Requerimen } \\
\text { to }\end{array}$ & $\begin{array}{l}\text { Paulo } \\
\text { Rodrigues } \\
\text { Ferreira ( } \\
\text { morador nas } \\
\text { minas da } \\
\text { Natividade }\end{array}$ & $\begin{array}{l}\text { rei [D. } \\
\text { José] }\end{array}$ & $\begin{array}{l}\text { Confirmaçã } \\
\text { o da carta } \\
\text { de } \\
\text { Sesmaria }\end{array}$ & $\begin{array}{l}\text { No arraial do } \\
\text { Carmo, na } \\
\text { paragem do } \\
\text { ribeirão das } \\
\text { Areias, } \\
\text { capitania de } \\
\text { Goiás. }\end{array}$ & \\
\hline 1357 & $\begin{array}{l}\text { Goiás, } 21 \\
\text { de Junho } \\
\text { de } 1766\end{array}$ & Carta & $\begin{array}{l}\text { João Manuel } \\
\text { de Melo } \\
\text { (governador e } \\
\text { capitão } \\
\text { general de } \\
\text { Goiás) }\end{array}$ & $\begin{array}{l}\text { rei [D. } \\
\text { José] }\end{array}$ & $\begin{array}{l}\text { Sobre a } \\
\text { Sesmaria } \\
\text { concedida a } \\
\text { Manuel } \\
\text { Moreira de } \\
\text { Carvalho, a } \\
\text { qual não foi } \\
\text { confirmada } \\
\text { por sua } \\
\text { Majestade }\end{array}$ & Goiás & $\begin{array}{l}\text { Por lhe ter } \\
\text { concedida três } \\
\text { léguas em quadra e } \\
\text { não em comprido, } \\
\text { como devia. }\end{array}$ \\
\hline 1366 & $\begin{array}{l}\text { Goiás, } 8 \\
\text { de Julho } \\
\text { de } 1766\end{array}$ & $\begin{array}{l}\text { Requerimen } \\
\text { to }\end{array}$ & $\begin{array}{l}\text { José Pereira } \\
\text { Lago } \\
\text { (capitão, } \\
\text { morador no } \\
\text { arraial do } \\
\text { Pilar) }\end{array}$ & $\begin{array}{l}\text { rei [D. } \\
\text { José] }\end{array}$ & $\begin{array}{l}\text { Confirmaçã } \\
\text { o da carta } \\
\text { de } \\
\text { Sesmaria }\end{array}$ & $\begin{array}{l}\text { Distante três } \\
\text { léguas e meia } \\
\text { do dito arraial, } \\
\text { junto ao rio } \\
\text { Vermelho, } \\
\text { capitania de } \\
\text { Goiás. } \\
\end{array}$ & \\
\hline 1397 & $\begin{array}{l}\text { Goiás, de } \\
\text { Agosto } \\
\text { de } 1766\end{array}$ & $\begin{array}{l}\text { Requerimen } \\
\text { to }\end{array}$ & $\begin{array}{l}\text { Manuel Luís } \\
\text { da Cunha ( } \\
\text { morador do } \\
\text { Tocantins) }\end{array}$ & $\begin{array}{l}\text { rei [D. } \\
\text { José] }\end{array}$ & $\begin{array}{l}\text { Mais três } \\
\text { anos para } \\
\text { dentro } \\
\text { deles cuidar } \\
\text { do pedido } \\
\text { de } \\
\text { confirmaçã } \\
\text { o de da } \\
\text { carta de } \\
\text { Sesmaria } \\
\end{array}$ & $\begin{array}{l}\text { Nas margens do } \\
\text { rio Maranhão, } \\
\text { capitania de } \\
\text { Goiás. }\end{array}$ & \\
\hline 1421 & $\begin{array}{l}\text { Goiás, } 08 \\
\text { de } \\
\text { Janeiro } \\
\text { de } 1767\end{array}$ & $\begin{array}{l}\text { Requerimen } \\
\text { to }\end{array}$ & $\begin{array}{l}\text { Antônio } \\
\text { Carneiro da } \\
\text { Silva } \\
\text { (morador em } \\
\text { Vila Boa de } \\
\text { Goiás) }\end{array}$ & $\begin{array}{l}\text { rei [D. } \\
\text { José] }\end{array}$ & $\begin{array}{l}\text { Confirmaçã } \\
\text { o da carta } \\
\text { de } \\
\text { Sesmaria }\end{array}$ & $\begin{array}{l}\text { No ribeirão } \\
\text { chamado } \\
\text { Fartura, por } \\
\text { detrás da Serra } \\
\text { Dourada, } \\
\text { capitania de } \\
\text { Goiás. }\end{array}$ & \\
\hline 1423 & $\begin{array}{l}\text { Goiás, } 12 \\
\text { de }\end{array}$ & $\begin{array}{l}\text { Requerimen } \\
\text { to }\end{array}$ & $\begin{array}{l}\text { Domingos } \\
\text { Alves }\end{array}$ & $\begin{array}{l}\text { rei [D. } \\
\text { José] }\end{array}$ & $\begin{array}{l}\text { Confirmaçã } \\
\text { o da carta }\end{array}$ & $\begin{array}{l}\text { Junto ao } \\
\text { ribeirão da }\end{array}$ & \\
\hline
\end{tabular}




\begin{tabular}{|c|c|c|c|c|c|c|c|}
\hline & $\begin{array}{l}\text { Janeiro } \\
\text { de } 1767\end{array}$ & & $\begin{array}{l}\text { Mendes } \\
\text { (morador em } \\
\text { São Patrício, } \\
\text { freguesia de } \\
\text { Nossa } \\
\text { Senhora do } \\
\text { Pilar) }\end{array}$ & & $\begin{array}{l}\text { de } \\
\text { Sesmaria }\end{array}$ & $\begin{array}{l}\text { Missa, capitania } \\
\text { de Goiás. }\end{array}$ & \\
\hline 1435 & $\begin{array}{l}\text { Goiás, } 17 \\
\text { de Junho } \\
\text { de } 1767\end{array}$ & $\begin{array}{l}\text { Carta de } \\
\text { Sesmaria }\end{array}$ & $\begin{array}{l}\text { João Manuel } \\
\text { de Melo( } \\
\text { Governador e } \\
\text { capitão- } \\
\text { general de } \\
\text { Goiás) } \\
\end{array}$ & $\begin{array}{l}\text { Antônio da } \\
\text { Silva Leita } \\
\text { (morador } \\
\text { no cocal) }\end{array}$ & $\begin{array}{l}\text { Conceder } \\
\text { umas terras }\end{array}$ & $\begin{array}{l}\text { No distrito de } \\
\text { Traíras, nas } \\
\text { margens do } \\
\text { Riacho Fundo, } \\
\text { capitania de } \\
\text { Goiás. }\end{array}$ & \\
\hline 1465 & $\begin{array}{l}\text { Goiás, } 28 \\
\text { de Julho } \\
\text { de } 1767\end{array}$ & $\begin{array}{l}\text { Requerimen } \\
\text { to }\end{array}$ & $\begin{array}{l}\text { Jeronimo } \\
\text { Martins da } \\
\text { Cunha(capitã } \\
\text { o) }\end{array}$ & $\begin{array}{l}\text { rei [D. } \\
\text { José] }\end{array}$ & $\begin{array}{l}\text { Confirmaçã } \\
\text { o da carta } \\
\text { de } \\
\text { Sesmaria }\end{array}$ & $\begin{array}{l}\text { No ribeirão dos } \\
\text { Bugres, na } \\
\text { região do } \\
\text { Campo Alegre, } \\
\text { capitania de } \\
\text { goiás }\end{array}$ & \\
\hline 1469 & $\begin{array}{l}\text { Goiás, } 23 \\
\text { de } \\
\text { Setembro } \\
1767 \\
\end{array}$ & $\begin{array}{l}\text { Requerimen } \\
\text { to }\end{array}$ & $\begin{array}{l}\text { José Pinto de } \\
\text { Magalhaes ( } \\
\text { padre) }\end{array}$ & $\begin{array}{l}\text { rei [D. } \\
\text { José] }\end{array}$ & $\begin{array}{l}\text { Confirmaçã } \\
\text { o da carta } \\
\text { de } \\
\text { Sesmaria } \\
\end{array}$ & $\begin{array}{l}\text { Capitania de } \\
\text { Goiás. }\end{array}$ & $\begin{array}{l}\text { Anexo } 1 \text { doc. (falta } \\
\text { a carta de } \\
\text { Sesmaria) AHU- } \\
\text { Goiás }\end{array}$ \\
\hline 1471 & $\begin{array}{l}\text { Goiás, } 09 \\
\text { de } \\
\text { Novembr } \\
\text { o de } 1767\end{array}$ & $\begin{array}{l}\text { Requerimen } \\
\text { to }\end{array}$ & $\begin{array}{l}\text { Luís Coelho } \\
\text { Furtado } \\
\text { (morador no } \\
\text { distrito do } \\
\text { Tocantins ) }\end{array}$ & $\begin{array}{l}\text { rei [D. } \\
\text { José] }\end{array}$ & $\begin{array}{l}\text { Confirmaçã } \\
\text { o da carta } \\
\text { de } \\
\text { Sesmaria }\end{array}$ & $\begin{array}{l}\text { Na paragem das } \\
\text { Pedras do } \\
\text { ribeirão das } \\
\text { Pedras, } \\
\text { capitania de } \\
\text { Goiás. }\end{array}$ & \\
\hline 1472 & $\begin{array}{l}\text { Goiás, } 09 \\
\text { de } \\
\text { Novembr } \\
\text { o de } 1767\end{array}$ & $\begin{array}{l}\text { Requerimen } \\
\text { to }\end{array}$ & $\begin{array}{l}\text { Joaquim de } \\
\text { Macedo } \\
\text { Pereira Horta } \\
\text { Rangel }\end{array}$ & $\begin{array}{l}\text { rei [D. } \\
\text { José] }\end{array}$ & $\begin{array}{l}\text { Confirmaçã } \\
\text { o da carta } \\
\text { de } \\
\text { Sesmaria }\end{array}$ & $\begin{array}{l}\text { Na paragem das } \\
\text { margens do rio } \\
\text { Maranhão, } \\
\text { capitania de } \\
\text { Goiás. }\end{array}$ & \\
\hline 1473 & $\begin{array}{l}\text { Goiás, } 09 \\
\text { de } \\
\text { novembr } \\
\text { o de } 1767 \\
\end{array}$ & $\begin{array}{l}\text { Requerimen } \\
\text { to }\end{array}$ & $\begin{array}{l}\text { Manuel } \\
\text { Lucas da } \\
\text { Cunha }\end{array}$ & $\begin{array}{l}\text { rei [D. } \\
\text { José] }\end{array}$ & $\begin{array}{l}\text { Confirmaçã } \\
\text { o da carta } \\
\text { de } \\
\text { Sesmaria } \\
\end{array}$ & $\begin{array}{l}\text { margens do rio } \\
\text { Maranhão, } \\
\text { capitania de } \\
\text { Goiás. }\end{array}$ & \\
\hline 1484 & $\begin{array}{l}\text { Goiás, } 11 \\
\text { de } \\
\text { Janeiro } \\
\text { de } 1768 \\
\end{array}$ & $\begin{array}{l}\text { Requerimen } \\
\text { to }\end{array}$ & $\begin{array}{l}\text { Francisco de } \\
\text { Campos Silva }\end{array}$ & $\begin{array}{l}\text { rei [D. } \\
\text { José] }\end{array}$ & $\begin{array}{l}\text { Confirmaçã } \\
\text { o da carta } \\
\text { de } \\
\text { Sesmaria } \\
\end{array}$ & $\begin{array}{l}\text { Na capitania de } \\
\text { Goiás. }\end{array}$ & \\
\hline 1487 & $\begin{array}{l}\text { Goiás, } 15 \\
\text { de Março } \\
\text { de } 1768\end{array}$ & $\begin{array}{l}\text { Requerimen } \\
\text { to }\end{array}$ & $\begin{array}{l}\text { Roque da } \\
\text { Silva Moreira }\end{array}$ & $\begin{array}{l}\text { rei [D. } \\
\text { José] }\end{array}$ & $\begin{array}{l}\text { Confirmaçã } \\
\text { o da carta } \\
\text { de } \\
\text { Sesmaria }\end{array}$ & $\begin{array}{l}\text { Na paragem } \\
\text { chamada } \\
\text { Furnas, distrito } \\
\text { de Meiaponte, } \\
\text { capitania de } \\
\text { Goiás. } \\
\end{array}$ & \\
\hline 1490 & $\begin{array}{l}\text { Goiás, } 15 \\
\text { de Abril } \\
\text { de } 1768\end{array}$ & $\begin{array}{l}\text { Requerimen } \\
\text { to }\end{array}$ & $\begin{array}{l}\text { José Carlos } \\
\text { Monteiro de } \\
\text { Araújo ( } \\
\text { morador em } \\
\text { Arraial da } \\
\text { Anta }\end{array}$ & $\begin{array}{l}\text { rei [D. } \\
\text { José] }\end{array}$ & $\begin{array}{l}\text { Confirmaçã } \\
\text { o da carta } \\
\text { de } \\
\text { Sesmaria }\end{array}$ & $\begin{array}{l}\text { Na barra do } \\
\text { córrego } \\
\text { Palmital, } \\
\text { cabeceiras do } \\
\text { rio do Peixe, } \\
\text { capitania de } \\
\text { Goiás. } \\
\end{array}$ & \\
\hline 1499 & $\begin{array}{l}\text { Goiás, } 16 \\
\text { de Junho } \\
\text { de } 1768\end{array}$ & $\begin{array}{l}\text { Requerimen } \\
\text { to }\end{array}$ & $\begin{array}{l}\text { Francisco } \\
\text { Lourenço da } \\
\text { Costa }\end{array}$ & $\begin{array}{l}\text { rei [D. } \\
\text { José] }\end{array}$ & $\begin{array}{l}\text { Confirmaçã } \\
\text { o da carta } \\
\text { de } \\
\text { Sesmaria }\end{array}$ & $\begin{array}{l}\text { No sitio } \\
\text { chamado } \\
\text { Canabrava, na } \\
\text { estrada que vai } \\
\text { para a chapada } \\
\text { de São Félix, } \\
\text { capitania de } \\
\text { Goiás. }\end{array}$ & \\
\hline 1521 & $\begin{array}{l}\text { Goiás, } 25 \\
\text { de } \\
\text { Agosto } \\
\text { de } 1768\end{array}$ & $\begin{array}{l}\text { Requerimen } \\
\text { to }\end{array}$ & $\begin{array}{l}\text { José Ribeiro } \\
\text { da Fonseca( } \\
\text { morador em } \\
\text { Vila boa) }\end{array}$ & $\begin{array}{l}\text { rei [D. } \\
\text { José] }\end{array}$ & $\begin{array}{l}\text { Confirmaçã } \\
\text { o da carta } \\
\text { de } \\
\text { Sesmaria }\end{array}$ & $\begin{array}{l}\text { Na paragem } \\
\text { chamada } \\
\text { Chapada, } \\
\text { distrito de Vila } \\
\text { Boa, capitania } \\
\text { de Goiás. } \\
\end{array}$ & \\
\hline 1539 & $\begin{array}{l}\text { Goiás, } 28 \\
\text { de } \\
\text { Fevereiro } \\
\text { de } 1769\end{array}$ & $\begin{array}{l}\text { Requerimen } \\
\text { to }\end{array}$ & $\begin{array}{l}\text { Bento Colaço } \\
\text { de Morais }\end{array}$ & $\begin{array}{l}\text { rei [D. } \\
\text { José] }\end{array}$ & $\begin{array}{l}\text { Confirmaçã } \\
\text { o da carta } \\
\text { de } \\
\text { Sesmaria }\end{array}$ & $\begin{array}{l}\text { No sitio } \\
\text { chamado Borda } \\
\text { do Mato Grosso }\end{array}$ & $\begin{array}{l}\text { Estrada velha de } \\
\text { povoado que parte, } \\
\text { da banda Norte, } \\
\text { com a . Margarida } \\
\text { da Silva, capitania }\end{array}$ \\
\hline
\end{tabular}




\begin{tabular}{|c|c|c|c|c|c|c|c|c|}
\hline & & & & & & & & de Goiás. \\
\hline 1540 & $\begin{array}{l}\text { Goiás, } 09 \\
\text { de Março } \\
\text { de } 1769\end{array}$ & $\begin{array}{l}\text { Requerimen } \\
\text { to }\end{array}$ & $\begin{array}{l}\text { Francisco } \\
\text { Ferreira dos } \\
\text { Santos ( } \\
\text { morador no } \\
\text { arraial de } \\
\text { Meiaponte) }\end{array}$ & $\begin{array}{l}\text { rei [D. } \\
\text { José] }\end{array}$ & $\begin{array}{l}\text { Confirmaçã } \\
\text { o da carta } \\
\text { de } \\
\text { Sesmaria }\end{array}$ & $\begin{array}{l}\text { Na paragem da } \\
\text { serra chamada } \\
\text { Caiçara, nas } \\
\text { cabeceiras do } \\
\text { ribeirão da } \\
\text { Água Limpa, } \\
\text { capitania de } \\
\text { Goiás. }\end{array}$ & & \\
\hline 1541 & $\begin{array}{l}\text { Goiás, } 09 \\
\text { de Março } \\
\text { de } 1769\end{array}$ & $\begin{array}{l}\text { Requerimen } \\
\text { to }\end{array}$ & $\begin{array}{l}\text { Antônio Jose } \\
\text { Ribeiro }\end{array}$ & $\begin{array}{l}\text { rei [D. } \\
\text { José] }\end{array}$ & $\begin{array}{l}\text { Confirmaçã } \\
\text { o da carta } \\
\text { de } \\
\text { Sesmaria }\end{array}$ & $\begin{array}{l}\text { No Ribeirão } \\
\text { chamado } \\
\text { Taquaraçu }\end{array}$ & $\begin{array}{l}\text { Na estrada } \\
\text { do Arraial } \\
\text { de Pilar } \\
\text { para o } \\
\text { Morrinhos, } \\
\text { capitania } \\
\text { de Goiás }\end{array}$ & \\
\hline 1542 & $\begin{array}{l}\text { Goiás, } 09 \\
\text { de Março } \\
\text { de } 1769\end{array}$ & $\begin{array}{l}\text { Requerimen } \\
\text { to }\end{array}$ & $\begin{array}{l}\text { Domingos } \\
\text { Vaz } \\
\text { Mascarenhas }\end{array}$ & $\begin{array}{l}\text { rei [D. } \\
\text { José] }\end{array}$ & $\begin{array}{l}\text { Confirmaçã } \\
\text { o da carta } \\
\text { de } \\
\text { Sesmaria }\end{array}$ & $\begin{array}{l}\text { No sitio } \\
\text { chamado } \\
\text { Abaixo do Poço } \\
\text { Grande }\end{array}$ & $\begin{array}{l}\text { Distante18 } \\
\text { léguas do } \\
\text { arraial de } \\
\text { Crixás, } \\
\text { capitania } \\
\text { de Goiás. }\end{array}$ & \\
\hline 1543 & $\begin{array}{l}\text { Goiás, } 09 \\
\text { de Março } \\
\text { de } 1769\end{array}$ & $\begin{array}{l}\text { Requerimen } \\
\text { to }\end{array}$ & $\begin{array}{l}\text { Manuel da } \\
\text { Costa Cabral }\end{array}$ & $\begin{array}{l}\text { rei [D. } \\
\text { José] }\end{array}$ & $\begin{array}{l}\text { Confirmaçã } \\
\text { o da carta } \\
\text { de } \\
\text { Sesmaria }\end{array}$ & $\begin{array}{l}\text { Manuel da } \\
\text { Costa Cabral }\end{array}$ & $\begin{array}{l}\text { No ribeirão } \\
\text { Pernatinga, } \\
\text { que } \\
\text { deságua no } \\
\text { São } \\
\text { Patrício, } \\
\text { capitania } \\
\text { de Goiás. }\end{array}$ & \\
\hline 1544 & $\begin{array}{l}\text { Goiás, } 09 \\
\text { de Março } \\
\text { de } 1769\end{array}$ & $\begin{array}{l}\text { Requerimen } \\
\text { to }\end{array}$ & $\begin{array}{l}\text { Miguel } \\
\text { Esteves de } \\
\text { Araújo }\end{array}$ & $\begin{array}{l}\text { rei [D. } \\
\text { José] }\end{array}$ & $\begin{array}{l}\text { Confirmaçã } \\
\text { o da carta } \\
\text { de } \\
\text { Sesmaria }\end{array}$ & $\begin{array}{l}\text { No sitio das } \\
\text { Almas, caminho } \\
\text { do arraial de } \\
\text { Morrinhos, } \\
\text { capitania de } \\
\text { Goiás. }\end{array}$ & & \\
\hline 1545 & $\begin{array}{l}\text { Goiás, } 09 \\
\text { de Março } \\
\text { de } 1769\end{array}$ & $\begin{array}{l}\text { Requerimen } \\
\text { to }\end{array}$ & $\begin{array}{l}\text { João Borges } \\
\text { de Andrade }\end{array}$ & $\begin{array}{l}\text { rei [D. } \\
\text { José] }\end{array}$ & $\begin{array}{l}\text { Confirmaçã } \\
\text { o da carta } \\
\text { de } \\
\text { Sesmaria }\end{array}$ & $\begin{array}{l}\text { No Ribeirão da } \\
\text { Paciência, } \\
\text { distrito do } \\
\text { arraial de Pilar, } \\
\text { capitania de } \\
\text { Goiás. }\end{array}$ & & \\
\hline 1549 & $\begin{array}{l}\text { Goiás, } 25 \\
\text { de Março } \\
\text { de } 1769\end{array}$ & $\begin{array}{l}\text { Requerimen } \\
\text { to }\end{array}$ & $\begin{array}{l}\text { Damião José } \\
\text { de Sá Pereira }\end{array}$ & $\begin{array}{l}\text { rei [D. } \\
\text { José] }\end{array}$ & $\begin{array}{l}\text { Confirmaçã } \\
\text { o da carta } \\
\text { de } \\
\text { Sesmaria }\end{array}$ & $\begin{array}{l}\text { No ribeirão dos } \\
\text { Macacos, } \\
\text { distrito de Pilar, } \\
\text { capitania de } \\
\text { Goiás. }\end{array}$ & & \\
\hline 1553 & $\begin{array}{l}\text { Goiás,07 } \\
\text { de Junho } \\
\text { de } 1769\end{array}$ & $\begin{array}{l}\text { Requerimen } \\
\text { to }\end{array}$ & $\begin{array}{l}\text { João da Silva } \\
\text { Lopes } \\
\text { (morador no } \\
\text { distrito da } \\
\text { Barra de } \\
\text { Palma) }\end{array}$ & $\begin{array}{l}\text { rei [D. } \\
\text { José] }\end{array}$ & $\begin{array}{l}\text { Confirmaçã } \\
\text { o da carta } \\
\text { de } \\
\text { Sesmaria }\end{array}$ & $\begin{array}{l}\text { Na paragem } \\
\text { junto a um } \\
\text { córrego que faz } \\
\text { barra do rio } \\
\text { chamado } \\
\text { Manuel Alves, } \\
\text { capitania de } \\
\text { Goiás. }\end{array}$ & & \\
\hline 1554 & $\begin{array}{l}\text { Goiás, } 07 \\
\text { de Junho } \\
\text { de } 1769\end{array}$ & $\begin{array}{l}\text { Requerimen } \\
\text { to }\end{array}$ & $\begin{array}{l}\text { João da Silva } \\
\text { Lopes } \\
\text { (morador no } \\
\text { distrito da } \\
\text { Barra de } \\
\text { Palma) }\end{array}$ & $\begin{array}{l}\text { rei [D. } \\
\text { José] }\end{array}$ & $\begin{array}{l}\text { Confirmaçã } \\
\text { o da carta } \\
\text { de } \\
\text { Sesmaria }\end{array}$ & $\begin{array}{l}\text { Na paragem } \\
\text { chamada } \\
\text { Fazenda } \\
\text { Espirito Santo, } \\
\text { distrito da Barra } \\
\text { da Palma, } \\
\text { capitania de } \\
\text { Goiás. }\end{array}$ & & \\
\hline 1600 & $\begin{array}{l}\text { Goiás, } 11 \\
\text { de Junho } \\
\text { de } 1770\end{array}$ & $\begin{array}{l}\text { Requerimen } \\
\text { to }\end{array}$ & $\begin{array}{l}\text { José Dias } \\
\text { Pais }\end{array}$ & $\begin{array}{l}\text { rei [D. } \\
\text { José] }\end{array}$ & $\begin{array}{l}\text { Confirmaçã } \\
\text { o da carta } \\
\text { de } \\
\text { Sesmaria }\end{array}$ & $\begin{array}{l}\text { Nos matos da } \\
\text { Paciência, } \\
\text { distrito de Vilas } \\
\text { Boas, capitania } \\
\text { de Goiás. }\end{array}$ & & \\
\hline 1604 & $\begin{array}{l}\text { Goiás, } 19 \\
\text { de Julho } \\
\text { de } 1770\end{array}$ & $\begin{array}{l}\text { Requerimen } \\
\text { to }\end{array}$ & $\begin{array}{l}\text { Gabriel da } \\
\text { Cruz de } \\
\text { Miranda }\end{array}$ & $\begin{array}{l}\text { rei [D. } \\
\text { José] }\end{array}$ & $\begin{array}{l}\text { Confirmaçã } \\
\text { o da carta } \\
\text { de } \\
\text { Sesmaria }\end{array}$ & $\begin{array}{l}\text { Ao pé do rio } \\
\text { São Bartolomeu } \\
\text {, no lugar } \\
\text { chamado } \\
\text { Barreiro, } \\
\text { capitania de }\end{array}$ & & \\
\hline
\end{tabular}




\begin{tabular}{|c|c|c|c|c|c|c|c|}
\hline & & & & & & Goiás. & \\
\hline 1606 & $\begin{array}{l}\text { Goiás, } 24 \\
\text { de Julho } \\
\text { de } 1770\end{array}$ & $\begin{array}{l}\text { Requerimen } \\
\text { to }\end{array}$ & $\begin{array}{l}\text { Dionísio } \\
\text { Francisco } \\
\text { Malheiros }\end{array}$ & $\begin{array}{l}\text { rei [D. } \\
\text { José] }\end{array}$ & $\begin{array}{l}\text { Confirmaçã } \\
\text { o da carta } \\
\text { de } \\
\text { Sesmaria }\end{array}$ & $\begin{array}{l}\text { No sitio } \\
\text { chamado } \\
\text { Ribeirão } \\
\text { Vermelho de } \\
\text { Cubas, } \\
\text { capitania de } \\
\text { Goiás. }\end{array}$ & \\
\hline 1607 & $\begin{array}{l}\text { Goiás, } 07 \\
\text { de } \\
\text { Agosto } \\
\text { de } 1770\end{array}$ & $\begin{array}{l}\text { Requerimen } \\
\text { to }\end{array}$ & $\begin{array}{l}\text { Antônio } \\
\text { Martins dos } \\
\text { Santos }\end{array}$ & $\begin{array}{l}\text { rei [D. } \\
\text { José] }\end{array}$ & $\begin{array}{l}\text { Confirmaçã } \\
\text { o da carta } \\
\text { de } \\
\text { Sesmaria }\end{array}$ & $\begin{array}{l}\text { No sitio do } \\
\text { Mato Grosso, } \\
\text { capitania de } \\
\text { Goiás. }\end{array}$ & \\
\hline 1622 & $\begin{array}{l}\text { Goiás, } 27 \\
\text { de } \\
\text { Outubro } \\
\text { de } 1770\end{array}$ & $\begin{array}{l}\text { Requerimen } \\
\text { to }\end{array}$ & $\begin{array}{l}\text { João } \\
\text { Damasceno } \\
\text { Soares ( } \\
\text { morador no } \\
\text { Córrego de } \\
\text { Jaraguá) }\end{array}$ & $\begin{array}{l}\text { rei [D. } \\
\text { José] }\end{array}$ & $\begin{array}{l}\text { Confirmaçã } \\
\text { o da carta } \\
\text { de } \\
\text { Sesmaria }\end{array}$ & $\begin{array}{l}\text { Nas vertentes } \\
\text { do ribeirão } \\
\text { chamado Rio } \\
\text { dos Patos, } \\
\text { distrito de } \\
\text { Meiaponte, } \\
\text { capitania de } \\
\text { Goiás. }\end{array}$ & \\
\hline 1628 & $\begin{array}{l}\text { Goiás, } 05 \\
\text { de } \\
\text { Dezembr } \\
\text { o de } 1770\end{array}$ & $\begin{array}{l}\text { Requerimen } \\
\text { to }\end{array}$ & $\begin{array}{l}\text { Francisco de } \\
\text { Sousa }\end{array}$ & $\begin{array}{l}\text { rei [D. } \\
\text { José] }\end{array}$ & $\begin{array}{l}\text { Confirmaçã } \\
\text { o da carta } \\
\text { de } \\
\text { Sesmaria }\end{array}$ & $\begin{array}{l}\text { Meia légua de } \\
\text { terra no sitio } \\
\text { para baixo do } \\
\text { ribeirão das } \\
\text { Contendas }\end{array}$ & $\begin{array}{l}\text { Distrito de Vila } \\
\text { Boa costeando o rio } \\
\text { Urú, capitania de } \\
\text { Goiás. }\end{array}$ \\
\hline 1635 & $\begin{array}{l}\text { Goiás, } 27 \\
\text { de } \\
\text { Fevereiro } \\
\text { de } 1770\end{array}$ & $\begin{array}{l}\text { Requerimen } \\
\text { to }\end{array}$ & $\begin{array}{l}\text { João Silva } \\
\text { Lopes }\end{array}$ & $\begin{array}{l}\text { rei [D. } \\
\text { José] }\end{array}$ & $\begin{array}{l}\text { Confirmaçã } \\
\text { o da carta } \\
\text { de } \\
\text { Sesmaria }\end{array}$ & $\begin{array}{l}\text { No distrito da } \\
\text { Barra da Palma, } \\
\text { na Fazenda } \\
\text { chamada } \\
\text { Espírito Santo, } \\
\text { capitania de } \\
\text { Goiás. }\end{array}$ & \\
\hline 1648 & $\begin{array}{l}\text { Goiás, } 12 \\
\text { de Junho } \\
\text { de } 1771\end{array}$ & $\begin{array}{l}\text { Requerimen } \\
\text { to }\end{array}$ & $\begin{array}{l}\text { Antônio } \\
\text { Vieira da } \\
\text { Silva( } \\
\text { morador em } \\
\text { São Félix) }\end{array}$ & $\begin{array}{l}\text { rei [D. } \\
\text { José] }\end{array}$ & $\begin{array}{l}\text { Confirmaçã } \\
\text { o da carta } \\
\text { de } \\
\text { Sesmaria }\end{array}$ & $\begin{array}{l}\text { No ribeirão da } \\
\text { Mutuca, no } \\
\text { caminho para } \\
\text { Cavalcante, } \\
\text { capitania de } \\
\text { Goiás. }\end{array}$ & \\
\hline 1650 & $\begin{array}{l}\text { Goiás, } 25 \\
\text { de Junho } \\
1771\end{array}$ & $\begin{array}{l}\text { Requerimen } \\
\text { to }\end{array}$ & $\begin{array}{l}\text { Manuel } \\
\text { Teixeira de } \\
\text { Oliveira ( } \\
\text { morador na } \\
\text { ribeira do } \\
\text { Paranã }\end{array}$ & $\begin{array}{l}\text { rei [D. } \\
\text { José] }\end{array}$ & $\begin{array}{l}\text { Confirmaçã } \\
\text { o da carta } \\
\text { de } \\
\text { Sesmaria }\end{array}$ & $\begin{array}{l}\text { Na paragem } \\
\text { chamada } \\
\text { Bocaina, } \\
\text { capitania de } \\
\text { Goiás. }\end{array}$ & \\
\hline 1655 & $\begin{array}{l}\text { Goiás, } 15 \\
\text { de Julho } \\
\text { de } 1771\end{array}$ & $\begin{array}{l}\text { Requerimen } \\
\text { to }\end{array}$ & $\begin{array}{l}\text { Manuel } \\
\text { Lucas da } \\
\text { Cunha ( } \\
\text { morador no } \\
\text { distrito do } \\
\text { Cocal) }\end{array}$ & $\begin{array}{l}\text { rei [D. } \\
\text { José] }\end{array}$ & $\begin{array}{l}\text { Confirmaçã } \\
\text { o da carta } \\
\text { de } \\
\text { Sesmaria }\end{array}$ & $\begin{array}{l}\text { Margens do rio } \\
\text { Maranhão }\end{array}$ & $\begin{array}{l}\text { Entre a roça que foi } \\
\text { de João Alves de } \\
\text { Braga até o Riacho } \\
\text { das Pedras, } \\
\text { capitania de Goiás. }\end{array}$ \\
\hline 1656 & $\begin{array}{l}\text { Goiás, } 15 \\
\text { de julho } \\
\text { de } 1771\end{array}$ & $\begin{array}{l}\text { Requerimen } \\
\text { to }\end{array}$ & $\begin{array}{l}\text { João Lopes } \\
\text { da Cunha( no } \\
\text { distrito do } \\
\text { Cocal }\end{array}$ & $\begin{array}{l}\text { rei [D. } \\
\text { José] }\end{array}$ & $\begin{array}{l}\text { Confirmaçã } \\
\text { o da carta } \\
\text { de } \\
\text { Sesmaria }\end{array}$ & $\begin{array}{lr}\text { Entre } & \text { as } \\
\text { sesmarias } & \text { de } \\
\text { José Rodrigues } \\
\text { Lobato r e } \\
\text { Manuel Ferreira } \\
\text { de r Castro } \\
\text { capitania r de } \\
\text { Goiás. }\end{array}$ & \\
\hline 1677 & $\begin{array}{l}\text { Goiás, } 05 \\
\text { de Maio } \\
\text { de } 1772\end{array}$ & $\begin{array}{l}\text { Requerimen } \\
\text { to }\end{array}$ & $\begin{array}{l}\text { Bernardo } \\
\text { José } \\
\text { Machado }\end{array}$ & $\begin{array}{l}\text { rei [D. } \\
\text { José] }\end{array}$ & $\begin{array}{l}\text { Confirmaçã } \\
\text { o da carta } \\
\text { de } \\
\text { Sesmaria }\end{array}$ & $\begin{array}{l}\text { No lugar } \\
\text { chamado São } \\
\text { Patrício, } \\
\text { capitania de } \\
\text { Goiás }\end{array}$ & \\
\hline 1678 & $\begin{array}{l}\text { Goiás, } 09 \\
\text { de Maio } \\
\text { de } 1772\end{array}$ & $\begin{array}{l}\text { Requerimen } \\
\text { to }\end{array}$ & $\begin{array}{l}\text { João } \\
\text { Gonçalves } \\
\text { Chaves } \\
\text { (padre) }\end{array}$ & $\begin{array}{l}\text { rei [D. } \\
\text { José] }\end{array}$ & $\begin{array}{l}\text { Confirmaçã } \\
\text { o da carta } \\
\text { de } \\
\text { Sesmaria }\end{array}$ & $\begin{array}{l}\text { No sítio do } \\
\text { ribeirão } \\
\text { vermelho, } \\
\text { capitania de } \\
\text { Goiás. }\end{array}$ & \\
\hline 1679 & $\begin{array}{l}\text { Goiás, 09 } \\
\text { Maio de } \\
1772\end{array}$ & Provisão & $\begin{array}{l}\text { Antônio } \\
\text { Vieira da } \\
\text { Silva }\end{array}$ & $\begin{array}{l}\text { rei [D. } \\
\text { José] }\end{array}$ & $\begin{array}{l}\text { Confirmaçã } \\
\text { o da carta } \\
\text { de } \\
\text { Sesmaria }\end{array}$ & $\begin{array}{l}\text { No lugar } \\
\text { chamado Olhos } \\
\text { D’Água, } \\
\text { caminho de } \\
\text { Cavalcante, }\end{array}$ & \\
\hline
\end{tabular}




\begin{tabular}{|c|c|c|c|c|c|c|c|}
\hline & & & & & & $\begin{array}{l}\text { junto ao } \\
\text { ribeirão da } \\
\text { Mutuca, } \\
\text { capitania de } \\
\text { Goiás }\end{array}$ & \\
\hline 1681 & $\begin{array}{l}\text { Goiás,06 } \\
\text { de julho } \\
\text { de } 1772\end{array}$ & $\begin{array}{l}\text { Requerimen } \\
\text { to }\end{array}$ & $\begin{array}{l}\text { Francisco } \\
\text { das Chagas } \\
\text { de Melo } \\
\text { Franco }\end{array}$ & $\begin{array}{l}\text { rei [D. } \\
\text { José] }\end{array}$ & $\begin{array}{l}\text { Confirmaçã } \\
\text { o da carta } \\
\text { de } \\
\text { Sesmaria }\end{array}$ & $\begin{array}{l}\text { No sertão do } \\
\text { Paraíba, distrito } \\
\text { do Arraial de } \\
\text { Meiaponte, na } \\
\text { paragem do rio } \\
\text { das Almas, } \\
\text { capitania de } \\
\text { Goiás. }\end{array}$ & \\
\hline 1704 & $\begin{array}{l}\text { Goiás, } 26 \\
\text { de } \\
\text { Novembr } \\
\text { o de } 1772\end{array}$ & $\begin{array}{l}\text { Requerimen } \\
\text { to }\end{array}$ & $\begin{array}{l}\text { Antônio da } \\
\text { Silva Leite } \\
\text { (morador no } \\
\text { distrito das } \\
\text { Minas de } \\
\text { Traíras) }\end{array}$ & $\begin{array}{l}\text { rei [D. } \\
\text { José] }\end{array}$ & $\begin{array}{l}\text { Confirmaçã } \\
\text { o da carta } \\
\text { de } \\
\text { Sesmaria }\end{array}$ & $\begin{array}{l}\text { Nas margens do } \\
\text { Riacho Fundo, } \\
\text { capitania de } \\
\text { Goiás. }\end{array}$ & \\
\hline 1710 & $\begin{array}{l}\text { Vila Boa, } \\
03 \text { de } \\
\text { Fevereiro } \\
\text { de } 1773\end{array}$ & Ofício & $\begin{array}{l}\text { José de } \\
\text { Almeida } \\
\text { Vasconcelos } \\
\text { de Soveral e } \\
\text { Carvalho } \\
\text { [governador- } \\
\text { general de } \\
\text { Goiás, barão } \\
\text { de } \\
\text { Mossamedes] } \\
\text {, barão de } \\
\text { Mossamedes } \\
\text { ] }\end{array}$ & $\begin{array}{l}\text { Martinho } \\
\text { de Melo e } \\
\text { Castro } \\
\text { (secretário } \\
\text { de estado } \\
\text { da Marinha } \\
\text { e } \\
\text { Ultramar }\end{array}$ & $\begin{array}{l}\text { Sobre a } \\
\text { ordem para } \\
\text { escolher á } \\
\text { Junta da } \\
\text { Fazenda } \\
\text { Real os } \\
\text { livros e } \\
\text { papéis que } \\
\text { se } \\
\text { encontram } \\
\text { na } \\
\text { Provedoria } \\
\text { Real, }\end{array}$ & & $\begin{array}{l}\text { Relativos á } \\
\text { administração e } \\
\text { arrecadação das } \\
\text { rendas e acerca do } \\
\text { cumprimento das } \\
\text { novas ordens } \\
\text { referentes á } \\
\text { concessão de } \\
\text { sesmaria. }\end{array}$ \\
\hline 1739 & $\begin{array}{l}\text { Lisboa, } \\
26 \text { Maio } \\
\text { de } 1773\end{array}$ & $\begin{array}{l}\text { Carta de } \\
\text { Sesmaria }\end{array}$ & $\begin{array}{l}\text { Antônio da } \\
\text { Silva Leite }\end{array}$ & $\begin{array}{l}\text { rei [D. } \\
\text { José] }\end{array}$ & $\begin{array}{l}\text { Confirmaçã } \\
\text { o da carta } \\
\text { de } \\
\text { Sesmaria }\end{array}$ & $\begin{array}{l}\text { No distrito de } \\
\text { Traíras, nas } \\
\text { margens do } \\
\text { Riacho Fundo, } \\
\text { capitania de } \\
\text { Goiás. }\end{array}$ & \\
\hline 1740 & $\begin{array}{l}\text { Goiás, } 05 \\
\text { de Junho } \\
\text { de } 1773\end{array}$ & $\begin{array}{l}\text { Requerimen } \\
\text { to }\end{array}$ & $\begin{array}{l}\text { Escolástica } \\
\text { Buena de } \\
\text { Camargo }\end{array}$ & $\begin{array}{l}\text { rei [D. } \\
\text { José] }\end{array}$ & $\begin{array}{l}\text { Confirmaçã } \\
\text { o da carta } \\
\text { de } \\
\text { Sesmaria } \\
\end{array}$ & $\begin{array}{l}\text { No distrito do } \\
\text { Arraial do Pilar, } \\
\text { capitania de } \\
\text { Goiás. } \\
\end{array}$ & \\
\hline 1784 & $\begin{array}{l}\text { Goiás, } 06 \\
\text { de } \\
\text { Setembro } \\
\text { de } 1774\end{array}$ & $\begin{array}{l}\text { Requerimen } \\
\text { to }\end{array}$ & $\begin{array}{l}\text { Balthazar } \\
\text { Gonçalves de } \\
\text { Carvalho }\end{array}$ & $\begin{array}{l}\text { rei [D. } \\
\text { José] }\end{array}$ & $\begin{array}{l}\text { Confirmaçã } \\
\text { o da carta } \\
\text { de } \\
\text { Sesmaria }\end{array}$ & $\begin{array}{l}\text { Situada na } \\
\text { Freguesia do } \\
\text { arraial de São } \\
\text { José, comarca } \\
\text { do Rio das } \\
\text { Mortes, } \\
\text { capitania de } \\
\text { Goiás. }\end{array}$ & \\
\hline 1785 & $\begin{array}{l}\text { Goiás, } 06 \\
\text { de } \\
\text { Setembro } \\
\text { de } 1773\end{array}$ & $\begin{array}{l}\text { Requerimen } \\
\text { to }\end{array}$ & $\begin{array}{l}\text { Domingos } \\
\text { Rodrigues } \\
\text { (morador no } \\
\text { arraial da } \\
\text { Natividade) }\end{array}$ & $\begin{array}{l}\text { rei [D. } \\
\text { José] }\end{array}$ & $\begin{array}{l}\text { Confirmaçã } \\
\text { o da carta } \\
\text { de } \\
\text { Sesmaria }\end{array}$ & $\begin{array}{l}\text { Situada } \\
\text { próximo ao Rio } \\
\text { do Peixe, } \\
\text { capitania de } \\
\text { Goiás. }\end{array}$ & \\
\hline 1786 & $\begin{array}{l}\text { Goiás, } 06 \\
\text { de } \\
\text { Setembro } \\
\text { de } 1773\end{array}$ & $\begin{array}{l}\text { Requerimen } \\
\text { to }\end{array}$ & $\begin{array}{l}\text { Antônio de } \\
\text { Oliveira }\end{array}$ & $\begin{array}{l}\text { rei [D. } \\
\text { José] }\end{array}$ & $\begin{array}{l}\text { Confirmaçã } \\
\text { o da carta } \\
\text { de } \\
\text { Sesmaria }\end{array}$ & $\begin{array}{l}\text { Situada } \\
\text { próximo ao } \\
\text { lugar chamado } \\
\text { Riachão, } \\
\text { capitania de } \\
\text { Goiás. }\end{array}$ & \\
\hline 1793 & $\begin{array}{l}\text { Goiás, } 12 \\
\text { de } \\
\text { Novembr } \\
\text { o de } 1774\end{array}$ & $\begin{array}{l}\text { Requerimen } \\
\text { to }\end{array}$ & $\begin{array}{l}\text { Caetano José } \\
\text { de Campos }\end{array}$ & $\begin{array}{l}\text { rei [D. } \\
\text { José] }\end{array}$ & $\begin{array}{l}\text { Confirmaçã } \\
\text { o da carta } \\
\text { de } \\
\text { Sesmaria }\end{array}$ & $\begin{array}{l}\text { No lugar } \\
\text { chamado } \\
\text { Retiro, } \\
\text { capitania de } \\
\text { Goiás. } \\
\end{array}$ & \\
\hline 1798 & $\begin{array}{l}\text { Goiás, } 20 \\
\text { de } \\
\text { Dezembr } \\
\text { o de } 1774\end{array}$ & $\begin{array}{l}\text { Carta de } \\
\text { Sesmaria }\end{array}$ & $\begin{array}{l}\text { José Ribeiro } \\
\text { da Fonseca } \\
\text { (morador de } \\
\text { Vila Boa) }\end{array}$ & $\begin{array}{l}\text { Rei [D. } \\
\text { José] }\end{array}$ & $\begin{array}{l}\text { Confirmaçã } \\
\text { o da carta } \\
\text { de } \\
\text { Sesmaria }\end{array}$ & $\begin{array}{l}\text { No ribeirão do } \\
\text { Ferreira, } \\
\text { próximo ao } \\
\text { Sítio de Tibaldo } \\
\text { Paes, capitania } \\
\text { de Goiás. }\end{array}$ & \\
\hline 1861 & $\begin{array}{l}\text { Goiás, } 03 \\
\text { de }\end{array}$ & $\begin{array}{l}\text { Requerimen } \\
\text { to }\end{array}$ & $\begin{array}{l}\text { Francisco } \\
\text { Xavier de }\end{array}$ & $\begin{array}{l}\text { rei [D. } \\
\text { José] }\end{array}$ & $\begin{array}{l}\text { Confirmaçã } \\
\text { o da carta }\end{array}$ & $\begin{array}{l}\text { Nos matos e } \\
\text { campos da }\end{array}$ & \\
\hline
\end{tabular}




\begin{tabular}{|c|c|c|c|c|c|c|c|}
\hline & $\begin{array}{l}\text { Outubro } \\
\text { de } 1776\end{array}$ & & Lima & & $\begin{array}{l}\text { de } \\
\text { Sesmaria }\end{array}$ & $\begin{array}{l}\text { Paciência, } \\
\text { distrito de } \\
\text { Vilaboa, } \\
\text { capitania de } \\
\text { Goiás. }\end{array}$ & \\
\hline 1899 & $\begin{array}{l}\text { Goiás, } 27 \\
\text { de } \\
\text { Novembr } \\
\text { o de } 1777\end{array}$ & $\begin{array}{l}\text { Requerimen } \\
\text { to }\end{array}$ & $\begin{array}{l}\text { Caetano } \\
\text { Cardoso de } \\
\text { Moraes }\end{array}$ & $\begin{array}{l}\text { Rainha } \\
\text { [Dona } \\
\text { Maria I] }\end{array}$ & $\begin{array}{l}\text { Confirmaçã } \\
\text { o da carta } \\
\text { de } \\
\text { Sesmaria }\end{array}$ & $\begin{array}{l}\text { No lugar } \\
\text { chamado } \\
\text { Bonito, } \\
\text { capitania de } \\
\text { Goiás. }\end{array}$ & \\
\hline 1911 & $\begin{array}{l}\text { Goiás, } 13 \\
\text { de } \\
\text { Fevereiro } \\
\text { de } 1778\end{array}$ & $\begin{array}{l}\text { Requerimen } \\
\text { to }\end{array}$ & $\begin{array}{l}\text { Francisco } \\
\text { Pereira Pinto }\end{array}$ & $\begin{array}{l}\text { Rainha } \\
\text { [Dona } \\
\text { Maria I] }\end{array}$ & $\begin{array}{l}\text { Confirmaçã } \\
\text { o da carta } \\
\text { de } \\
\text { Sesmaria }\end{array}$ & $\begin{array}{l}\text { No sítio } \\
\text { chamado Lages, } \\
\text { limite com o } \\
\text { Arraial de Pilar, } \\
\text { capitania de } \\
\text { Goiás. }\end{array}$ & \\
\hline 1940 & $\begin{array}{l}\text { Goiás, } 14 \\
\text { de } \\
\text { Outubro, } \\
1778\end{array}$ & $\begin{array}{l}\text { Requerimen } \\
\text { to }\end{array}$ & $\begin{array}{l}\text { Caetano } \\
\text { Gonçalves de } \\
\text { Bastos }\end{array}$ & $\begin{array}{l}\text { Rainha } \\
{[\text { Dona }} \\
\text { Maria I] }\end{array}$ & $\begin{array}{l}\text { Confirmaçã } \\
\text { o da carta } \\
\text { de } \\
\text { Sesmaria }\end{array}$ & $\begin{array}{l}\text { Ribeirão de } \\
\text { Santa Luzia, } \\
\text { capitania de } \\
\text { Goiás. }\end{array}$ & \\
\hline 1941 & $\begin{array}{l}\text { Goiás, } 16 \\
\text { de } \\
\text { Outubro } \\
\text { de } 1778\end{array}$ & $\begin{array}{l}\text { Requerimen } \\
\text { to }\end{array}$ & $\begin{array}{l}\text { José Antônio } \\
\text { de Araújo }\end{array}$ & $\begin{array}{l}\text { Rainha } \\
{[\text { Dona }} \\
\text { Maria I] }\end{array}$ & $\begin{array}{l}\text { Confirmaçã } \\
\text { o da carta } \\
\text { de } \\
\text { Sesmaria }\end{array}$ & $\begin{array}{l}\text { Na paragem da } \\
\text { Barra do rio das } \\
\text { Almas, próximo } \\
\text { às minas de } \\
\text { Pilar, capitania } \\
\text { de Goiás. }\end{array}$ & . \\
\hline 1943 & $\begin{array}{l}\text { Goiás, } 17 \\
\text { de } \\
\text { Outubro } \\
\text { de } 1778\end{array}$ & $\begin{array}{l}\text { Requerimen } \\
\text { to }\end{array}$ & $\begin{array}{l}\text { Batista José } \\
\text { da Rocha }\end{array}$ & $\begin{array}{l}\text { Rainha } \\
\text { [Dona } \\
\text { Maria I] }\end{array}$ & $\begin{array}{l}\text { Confirmaçã } \\
\text { o da carta } \\
\text { de } \\
\text { Sesmaria }\end{array}$ & $\begin{array}{l}\text { Na paragem do } \\
\text { Jaguará. }\end{array}$ & $\begin{array}{l}\text { Na outra parte do } \\
\text { rio das Almas, } \\
\text { chamado } \\
\text { Fazendinha, } \\
\text { capitania de Goiás. }\end{array}$ \\
\hline 1950 & $\begin{array}{l}\text { Goiás, } 23 \\
\text { de } \\
\text { Novembr } \\
\text { o de } 1778\end{array}$ & $\begin{array}{l}\text { Requerimen } \\
\text { to }\end{array}$ & $\begin{array}{l}\text { Júlio de Brito } \\
\text { Peixoto }\end{array}$ & $\begin{array}{l}\text { Rainha } \\
{[\text { Dona }} \\
\text { Maria I] }\end{array}$ & $\begin{array}{l}\text { Confirmaçã } \\
\text { o da carta } \\
\text { de } \\
\text { Sesmaria }\end{array}$ & $\begin{array}{l}\text { Nas vizinhanças } \\
\text { do rio Preto, } \\
\text { capitania de } \\
\text { Goiás. }\end{array}$ & \\
\hline 1958 & $\begin{array}{l}\text { Goiás, } \\
1779\end{array}$ & $\begin{array}{l}\text { Requerimen } \\
\text { to }\end{array}$ & $\begin{array}{l}\text { Antônio José } \\
\text { pessoa }\end{array}$ & $\begin{array}{l}\text { Rainha } \\
{[\text { Dona }} \\
\text { Maria I] }\end{array}$ & $\begin{array}{l}\text { Confirmaçã } \\
\text { o da carta } \\
\text { de } \\
\text { Sesmaria }\end{array}$ & $\begin{array}{l}\text { Situada no } \\
\text { distrito de Pilar }\end{array}$ & $\begin{array}{l}\text { Entre o ribeirão de } \\
\text { São Pedro e São } \\
\text { Paulo, capitania de } \\
\text { Goiás. }\end{array}$ \\
\hline 1966 & $\begin{array}{l}\text { Goiás, } 22 \\
\text { de } \\
\text { Fevereiro } \\
\text { de } 1779\end{array}$ & $\begin{array}{l}\text { Requerimen } \\
\text { to }\end{array}$ & $\begin{array}{l}\text { Vicente José } \\
\text { de Sant'Ana }\end{array}$ & $\begin{array}{l}\text { Rainha } \\
{[\text { Dona }} \\
\text { Maria I] }\end{array}$ & $\begin{array}{l}\text { Confirmaçã } \\
\text { o da carta } \\
\text { de } \\
\text { Sesmaria }\end{array}$ & $\begin{array}{l}\text { Na paragem do } \\
\text { ribeirão } \\
\text { chamado Sousa, } \\
\text { capitania de } \\
\text { Goiás. }\end{array}$ & \\
\hline 1971 & $\begin{array}{l}\text { São } \\
\text { Félix, } 18 \\
\text { Março de } \\
1779\end{array}$ & $\begin{array}{l}\text { Requerimen } \\
\text { to }\end{array}$ & $\begin{array}{l}\text { Manuel } \\
\text { Lopes } \\
\text { Rapozo }\end{array}$ & $\begin{array}{l}\text { Rainha } \\
{[\text { Dona }} \\
\text { Maria I] }\end{array}$ & $\begin{array}{l}\text { Confirmaçã } \\
\text { o da carta } \\
\text { de } \\
\text { Sesmaria }\end{array}$ & $\begin{array}{l}\text { No Campo } \\
\text { Grande, } \\
\text { capitania de } \\
\text { Goiás. }\end{array}$ & \\
\hline 1976 & $\begin{array}{l}\text { Goiás, } 12 \\
\text { de Junho } \\
\text { de } 1779\end{array}$ & $\begin{array}{l}\text { Requerimen } \\
\text { to }\end{array}$ & $\begin{array}{l}\text { Antônio } \\
\text { Ferreira } \\
\text { Gomes( } \\
\text { morador nas } \\
\text { Minas de } \\
\text { Goiás) }\end{array}$ & $\begin{array}{l}\text { Rainha [D'. } \\
\text { Maria I] }\end{array}$ & $\begin{array}{l}\text { Confirmaçã } \\
\text { o da carta } \\
\text { de } \\
\text { Sesmaria }\end{array}$ & $\begin{array}{l}\text { Situada no } \\
\text { córrego do } \\
\text { Monjolo, } \\
\text { capitania de } \\
\text { Goiás. }\end{array}$ & \\
\hline 1982 & $\begin{array}{l}\text { Goiás, } 20 \\
\text { Julho de } \\
1779\end{array}$ & $\begin{array}{l}\text { Requerimen } \\
\text { to }\end{array}$ & $\begin{array}{l}\text { Manuel Luís } \\
\text { Lisboa }\end{array}$ & $\begin{array}{l}\text { Rainha [D'. } \\
\text { Maria I] }\end{array}$ & $\begin{array}{l}\text { Confirmaçã } \\
\text { o da carta } \\
\text { de } \\
\text { Sesmaria }\end{array}$ & $\begin{array}{l}\text { No sertão } \\
\text { chamado } \\
\text { Corriola, } \\
\text { distrito de São } \\
\text { Félix, capitania } \\
\text { de Goiás. }\end{array}$ & \\
\hline 1984 & $\begin{array}{l}\text { Goiás, } 26 \\
\text { de } \\
\text { Agosto } \\
\text { de } 1779\end{array}$ & $\begin{array}{l}\text { Requerimen } \\
\text { to }\end{array}$ & $\begin{array}{l}\text { João Ribeiro } \\
\text { Raposo } \\
\text { (capitão) }\end{array}$ & $\begin{array}{l}\text { Rainha [D'. } \\
\text { Maria I] }\end{array}$ & $\begin{array}{l}\text { Confirmaçã } \\
\text { o da carta } \\
\text { de } \\
\text { Sesmaria }\end{array}$ & $\begin{array}{l}\text { Nas vizinhanças } \\
\text { do Urú, } \\
\text { capitania de } \\
\text { Goiás. }\end{array}$ & \\
\hline 2013 & $\begin{array}{l}\text { Goiás, } 30 \\
\text { de Abril } \\
\text { de } 1781\end{array}$ & $\begin{array}{l}\text { Requerimen } \\
\text { to }\end{array}$ & $\begin{array}{l}\text { Álvaro } \\
\text { Gomes Leal } \\
\text { (morador do } \\
\text { Tocatins) }\end{array}$ & $\begin{array}{l}\text { Rainha [D'. } \\
\text { Maria I] }\end{array}$ & $\begin{array}{l}\text { Confirmaçã } \\
\text { o da carta } \\
\text { de } \\
\text { Sesmaria }\end{array}$ & $\begin{array}{l}\text { No sitio do } \\
\text { ribeirão } \\
\text { chamado Aca-a- } \\
\text { Vida, vertentes } \\
\text { do rio } \\
\text { Bagagem, } \\
\text { capitania de } \\
\text { Goiás. }\end{array}$ & \\
\hline 2017 & $\begin{array}{l}\text { Goiás, } 01 \\
\text { Julho de }\end{array}$ & $\begin{array}{l}\text { Requerimen } \\
\text { to }\end{array}$ & $\begin{array}{l}\text { João Teixeira } \\
\text { Chaves ( }\end{array}$ & $\begin{array}{l}\text { Rainha [D'. } \\
\text { Maria I] }\end{array}$ & $\begin{array}{l}\text { Confirmaçã } \\
\text { o da carta }\end{array}$ & $\begin{array}{l}\text { Na paragem de } \\
\text { um córrego }\end{array}$ & \\
\hline
\end{tabular}




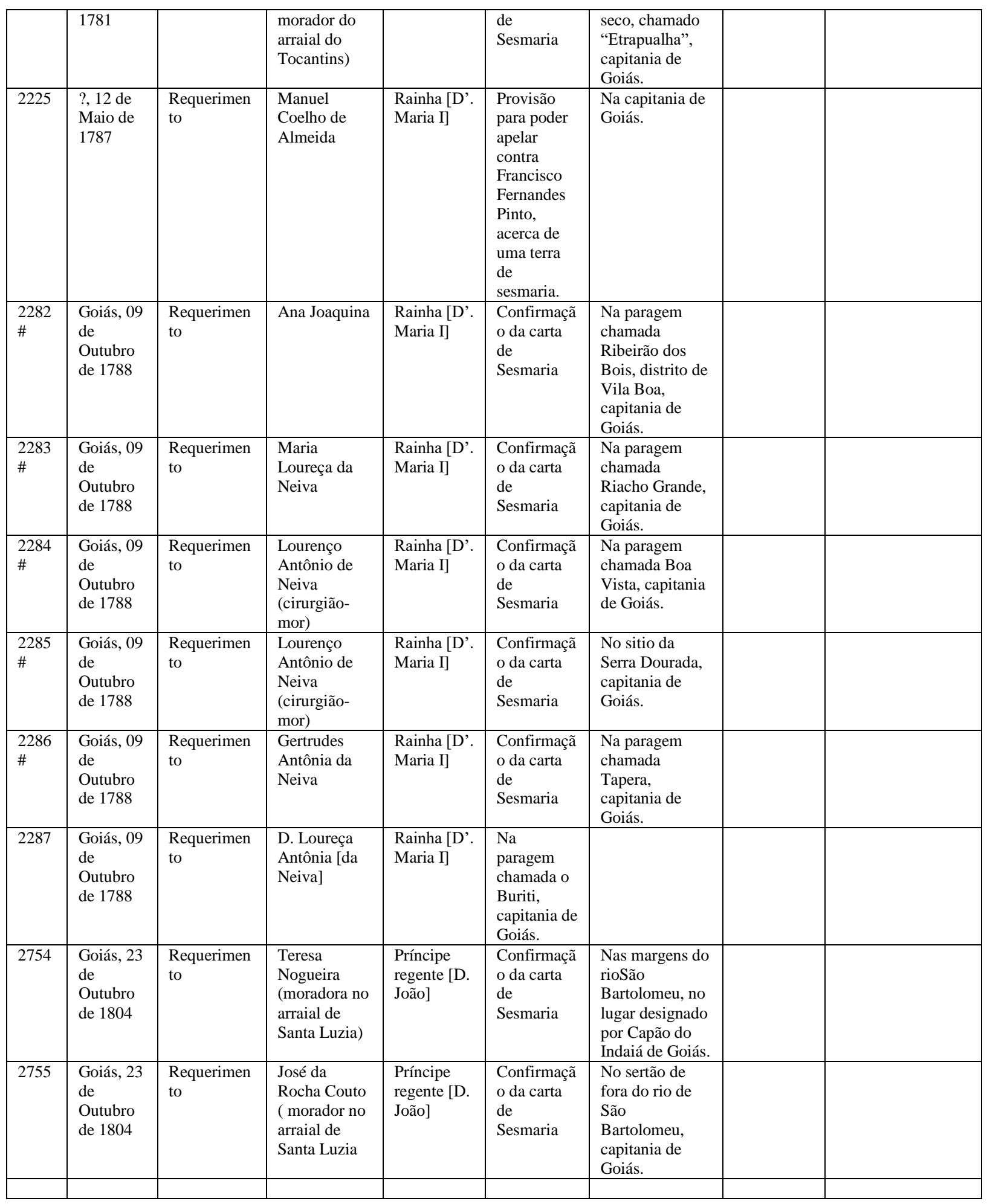

\section{REFERÊNCIAS}

ABREU, J. C. Capítulos de história colonial. www.terra.com.br/virtualbooks, 2002.

ALENCAR, Maria Amélia de. Estruturas fundiárias em Goiás: consolidação e mudanças (18501910). Goiânia: EdUCG, 1993. 
BERTRAN, Paulo. História da Terra e do Homem no Planalto Central. Brasília: Solo, 1994.

BERWANGNER, Ana Regina; LEAL, João Eurípedes Franklin. Noções de Paleografia e Diplomática. 3. Ed. Rev. E ampl. - Santa Maria: Ed. Da UFSM; 2008.

BURKUE, Peter. A escrita da História. Novas Perspectivas. Ed. Unesp.

CORTESÃO, Jaime. História do Brasil nos velhos mapas. Tomo I. Imprensa NACIONAL. Casa da Moeda. Lisboa, 2009.

CARDOSO, Ciro Flamarion \& VAINFAS, Ronaldo (Org.) Domínios da História.

FAORO, Raymundo. Os donos do poder. 1996.

FARIA, Sheila de Castro. A colônia em movimento: fortuna e família no cotidiano colonial. Rio de Janeiro: Nova Fronteira, 1998.

GOFF, Le. A nova História. Ed. Martins Fontes.

IANNI, O. A luta pela terra. Petrópolis-RJ: Vozes, 1978.

KANTOR, Íris. Mapas em trânsito: projeções cartográficas e processo de emancipação política do Brasil (1779-1822). Araucária, vol. 12, núm. 24, 2010, pp. 110-123 Universidad de Sevilla - Espana.

LACOSTE, Yves. A Geografia - Isso serve em primeiro lugar, para fazer a guerra. 12 ed. São Paulo: Papirus, 2006.

LEITE, Serafim. História da Companhia de Jesus no Brasil, Tomo II (Século XVI -- A Obra), p. 545-568. Rio de Janeiro: Civilização Brasileira, 1939.

NEVES, José Luís. Pesquisa qualitativa - características, usos e possibilidades. Caderno de Pesquisas em Administração. São Paulo, V.1, N.3, 2o semestre/1996.

ORLANDI, Eni Pulcinelli. Discurso e Leitura. 8o Ed. São Paulo, Cortez, 2008.

OSÓRIO, Helen. Apropriação da terra no Rio Grande de São Pedro e a formação do espaço Platino (mestrado, UFRGS, 1990).

PALACIN, L. O século do ouro em Goiás. Goiânia: Oriente, 1979.

PORTO, Walter Costa. O sistema sesmarial no Brasil. Coleção Temas Brasileiros. Brasília, V.1, sd.

ROCHA Jr, Deusdedith Alves; VIEIRA Jr, Wilson e CARDOSO, Rafael Carvalho C. Viagem pela estrada real dos Goyazes. Brasília: Paralelo 15, 2006.

SALLES, Gilka V. F. Economia e escravidão na capitania de Goiás. Goiânia: EdUFG, 1992. 
SEEMAN, Jorn. A toponímia como construção histórico-cultural. O exemplo dos municípios do estado do Ceará. Vivência, n.29, 2005, p.207-224.

SILVA, Vanda da. A concessão de sesmarias na capitania de Mato Grosso. Fronteiras: Revista de História. Dourados-MS, V.17, N.29, pp.11-33, 2015 (acesso em 01/04/2016).

SOUSA, Alexandre Melo de. Estudo toponímico dos lagos acreanos. recantodasletras.com.br - acessado em 11/02/2016.

VARNHAGEM, A. História geral do Brazil. Rio de Janeiro, (2 tomos) 1857. 